\title{
MEDIJSKA ZASTUPLJENOST POLITIČKIH OPCIJA I GRAĐANSKO IZBORNO PONAŠANJE (Case Study: Hrvatski parlamentarni izbori 2003.godine)
}

\author{
Mario Plenković1, Slobodan Hadžić ${ }^{2}$, Mladen Kučiš ${ }^{2}$ \\ Sveučilište u Zagrebu, Grafički fakultet, Zagreb, Hrvatska \& Alma Mater Europaea - ECM E Univerza v Mariboru, \\ Fakulteta za elektrotehniko, računalništvo in informatiko, Inštitut za medijske komunikacije, Maribor, Slovenija ${ }^{1}$; Hrvatsko \\ komunikološko društvo, Zagreb, Hrvatska
}

Sažetak

U radu je provedeno istraživačko, politološko i komunikološko istraživanje dijalektike medijske /ne/moći u procesu izbornog građanskog ponašanja na primjeru hrvatskih parlamentarnih izbora 2003. godine. Istraživanje obuhvaća vremenske granice od 1. rujna do 30. studenoga 2003. godine. Izabrana metodologija i primijenjene istraživačke metode usklađene su sa suvremenim istraživačkim trendovima koji se primjenjuju u sličnim medijskim istraživanjima i istraživanjima izbornih i političkih kampanja. Autori ukazuju na svu složenost proučavanja ove problematike koja zaokuplja pažnju recentne komunikološke i politološke znanstvene javnosti. Polazna istraživačka hipoteza u potpunosti je potvrdila predviđane istraživačke rezultate. Autorska istraživačka koncentracija usredotočena je na ispitivanje međusobnih korelacija između medijske zastupljenosti političkih opcija, osoba i izbornog građanskog ponašanja. Provedena je i induktivno-deduktivna analiza medijskog predstavljanja $\mathrm{u}$ korelaciji $\mathrm{s}$ utrošenim financijskim sredstvima za promidžbu i propagandnu kampanju. Dobiveni rezultati pokazuju da ne postoji značajniji uzročno posljedični odnos između medijske zastupljenosti i izbornog građanskog ponašanja. U zaključnom interpretiranju dobivenih rezultata je vidljivo da se stavovi o izbornoj preferenciji birača, prije izborne kampanje, nisu bitno izmijenili tijekom medijske promidžbene i propagandne izborne građanske izloženosti. Na temelju publiciranog članka „Dijalektika medijske moći i izborno građansko ponašanje (Hrvatski parlamentarni izbori 2003.), Informatol, Vol.39,No. 1,2006., održana je politološka i komunikološka retrospektivna rasprava na temu Case Study analiza "Hrvatski parlamentarni izbori 2003.godine“. Istraživanje je prezentirano, u povodu obilježavanja 50. obljetnice znanstvenog časopisa INFORMATOLOGIA (1969. - 2019.), na 25. International scientific conference „, SOCIETY AND TECHNOLOGY 2019 („DIT 2019“ - Dr. Juraj Plenković), Opatija, 28. - 30.06. 2019.

Ključne riječi

Parlamentarni izbori, mediji, oglašavanje 


\section{Uvod}

Medijska (ne)moć, javnost, politika, izbori i izborno građansko ponašanje uvijek privlači izuzetnu građansku pozornost a posebice pozornost stručne i znanstvene relevantne javnosti. Novije povijesno medijsko i izborno građansko ponašanje sve više određuju novi medijski procesi, nove medijske tehnologije, snažno širenje komuniciranja i stvaranje novog komunikacijskog izbornog svijeta kojeg sve više određuje novi tehnološki razvijeni revolucionarni mrežni svijet građana Interneta. Novo istraživačko politološko i komunikološko proučavanje dijalektike medijske (ne)moći u procesu građanskog ponašanja, odnosno (ne)moći medijskog komuniciranja, kod nas i u svijetu, u kontekstu razmatranja izbornog građanskog ponašanja ove problematike na pozornicu građanskog komuniciranja promatra položaj i ulogu medijsko komuniciranja, posebice ulogu i funkciju medija masovnog komuniciranja na svim razinama komuniciranja: lokalno, regionalno, nacionalno i globalno. Medijsko komuniciranje u procesu izbornog građanskog ponašanja postaje proces (ne)diskurzivne kompetitivnosti, suočavanje i odmjeravanje moći gdje svaki subjekt izbornog ponašanja želi dokazati svoju umnu, kulturnu, političku, gospodarsku, nacionalnu i građansku superiornost.

\section{Parlamentarni izbori, mediji i građansko ponašanje}

\subsection{Polazna hipoteza i istraživačka orijentacija}

Parlamentarni izbori u Hrvatskoj koji su održani 23. studenoga 2003. godine bili su predmet našeg istraživačkog interesa. U razdoblju od 1.rujna do 23. studenoga 2003. godine obavljeno je izuzetno opsežno empirijsko istraživanje medijske zastupljenosti svih izbornih građanskih i stranačkih opcija na političkoj sceni Hrvatske u cilju utvrđivanja možebitne korelacije između medijske zastupljenosti i izbornog ponašanja.

Polazna istraživačka hipoteza pretendira na moguće istraživačke rezultate koji trebaju hipotetski pokazati i ukazati i na mogući utjecaj medija $\mathrm{u}$ procesu izbornog građanskog ponašanja. Istraživačka orijentacija i sam istraživački problem već punih pedesetak istraživačkih godina zaokuplja pozornost svjetske politološke i komunikološke znanstvene i stručne literature iz znanstvene grane politologije i komunikologije odnosno medijske komunikologije.Možebitni dobiveni istraživački rezultati mogu se kretati u rasponu od medijskog glorificiranja do minoriziranja medijskih utjecaja na ponašanje relevantnih i izloženih javnosti.

\subsection{Moć medija i moć nad medijima}

Komunikološka znanstvena relevantna javnost je u suglasna u pogledu velike medijske moći koja se odnosi na moć stvaranja slike svijeta (tzv. diskurzivnu moć), moć dozvole prava pristupa mediju (koja je uglavnom namijenjena onima čije interese mediji odražavaju - politici, oglašavačkoj industriji, interesima vlasnika) i moći utjecaja na postupke vlada i država (posebno $u$ novostvorenom kontekstu korporativne medijske industrije). $\mathrm{U}$ komunikativnim izbornim interakcijama prevladavaju elementi strateške dominacije $u$ kojoj se odmjeravaju osobni, grupni, politički i nacionalni interesi. Dosadašnje teorije komunikacijske interakcije /1/ gradile su se na pretpostavkama simboličkog interakcionizma i na Habermasovoj teoriji komunikacijske akcije. Tradicionalne teorije su usuglašavale procese konsenzusnog sporazumijevanja. Nova komunikativna paradigma se temelji na pretpostavci da je komuniciranje oblik strateške interakcije koja sadrži dva proturječna procesa: proces približavanja, konjunkciju dviju ličnosti, dvaju identiteta kao i proces udaljavanja, disjunkciju dviju ličnosti, odnosno čuvanje identiteta vlastitog interesa i nadmoći.

Nadalje, kao što postoji moć medija, tako postoji i moć nad medijima, najčešće $u$ obliku državnog/političkog nadzora medija. Taj nadzor najčešće se manifestira kroz regulatorno djelovanje vlada, odnosno kroz definiranje medijske politike koja se odražava putem sustava upravljanja informacijama, odnosno omogućavanjem ili uskraćivanjem prava na informacije.

Moć nad medijima ostvaruju i svi oni čije interese mediji odražavaju, a stupanj moći i 
nadzora nad njima ovisi uglavnom o stupnju ovisnosti medija i interesu kojega medijski odražavaju. Prema provedenim recentnim istraživanjima /2/ informativno-političke televizijske emisije preko $43 \%$ financijskih prihoda ostvaruju od medijsko-oglašavačke industrije) čime se podređuju u poziciju ovisnost koju dirigira oglašavačka industrija.

Referentna istraživanja ekonomije medija ukazuju da u procesu koncentracije kapitala profitnost predstavlja temelj opstojnosti i širenja medijskog carstva, pa time i moći nad medijima koju ostvaruju vlasnici medija. Vlasnici medija moć nad medijima ostvaruju i zadirući na razne načine u uređivačku politiku javnih glasila, pri čemu je najpoznatiji onaj da se izborom kadrova osigurava promicanje željene uređivačke politike. Pritom nisu rijetki slučajevi izravnog uplitanja vlasnika u uređivačku politiku glasila/3/.

Međuzavisnost polja interesa i odmjeravanja snaga moći između vlasnika i medija, medijavlasnika i publike, države i medija, javnosti i države preko medijski posredovanih poruka, vlasnika i njegove profitne ovisnosti (prvenstveno o oglašavačkoj industriji) ukazuje na svu složenost razmatranja problematike utjecaja medija. Intenzitet odnosa između navedenih subjekata nije jednak $u$ svim zemljama i ovisi o: stupnju deregulacije medijskog tržišta, stupnju koncentracije vlasništva, razvijenosti gospodarstva, demokratskih tradicija itd. Ujedno, s druge točke gledišta, potrošnje medijskih informacija od strane pojedinca, način interpretacije informacija (pridavanje značenja), sociokulturne varijable dodatno otežavaju proces donošenje čvrstih medijskih zaključaka.

\subsection{Utjecaj medija}

Mediji, dakako, u našim glavama stvaraju sliku svijeta (diskurzivna moć). Brojne teorijske studije $\mathrm{i}$ rasprave o tome govore: Teorija uniformnog učinka/ svemoći ili takozvana mehanicistička teorija prema kojoj svaki podražaj daje odgovor (S-R); Teorija selektivnog učinka koja se temelji na individualnim razlikama - na obilježjima skupine, pojedinca, na društvenom kontekstu u trenucima prijema informacije, te na koristi i zadovoljstvu; Interpretacijski model - publika prima poruke i interpretira ih na svoj način. Težište istraživanja premješta se s razmišljanja o tome što mediji čine s ljudima prema istraživanjima o tome što ljudi čine s medijima. Varijacija interpretacijskoga modela je strukturirani interpretacijski model koji sugerira postojanje preferencijalnog čitanja ili dominantne poruke koju strukturira kulturni kontekst publike. Poststrukturalizam u dijelu dekonstrukcije literarnih tekstova i kritičkog pisanja otkriva oblike manipulacije $\mathrm{u}$ domeni političkog jezika /4/.

Curtice i Smetko (1994.) zaključuju: »Mnogi glasači, čini se, i dalje promatraju novinske izvještaje (i gledaju televizijske vijesti) kroz stranački filtar koji im omogućava ignoriranje politički neprikladne poruke»/5/

William Miller (1991.) »smatra da se medijski učinci moraju vezati za upotrebu medija, a da upotreba varira. Ona se mijenja ovisno o vrsti cilja za kojeg ljudi koriste medije...i mijenja se ovisno o okolnostima u kojima se mediji koriste (društveno podrijetlo korisnika)...U svom istraživanju Miller tvrdi da su učinci tiska bili vidljivi u stavovima i ponašanju birača.»/6/ Dok s jedne strane većina autora priznaje utjecaj medija,aligaograničavanizomposredujućihvarij abli/7/, Fanov i Timsov »ideodinamički» prediktivni model nedvosmisleno utvrđuje utjecaj medija na izborno ponašanje, a rezultati njegovih istraživanja pokazuju veću točnost od istraživanja javnoga mnijenja.

Predviđanja povjerenja potrošača na temelju tiskovnih objava istraživanje je koje je obavljeno 1991. godine primjenom naznačenog modela i njegovi rezultati su pokazali:

- podudarnost s Indeksom raspoloženja potrošača

- postojanje značajnog utjecaja vijesti na javno mnijenje (u ovom slučaju na raspoloženje potrošača)

Informacija je i roba i moć. Roba je jer podliježe svim zakonitostima robne proizvodnje koje su $\mathrm{u}$ medijskoj produkciji specifične zbog potrebe aktualnosti, inscenacije događaja i ostalih specifičnosti proizvodnje i distribucije informacija, a moć je jer onome tko informaciju nadzire omogućava dobivanje suglasnosti za provođenje vlastite volje. 


\subsection{Političke stranke i politička komunikacija}

Hrvatska politička scena je od početka svog višestranačkog konstituiranja početkom 1990-ih godina prošla razne faze, i to:

- od izuzetno velikog broja stranaka s početka višestranačja, do pada broja stranaka koje sudjeluju u parlamentarnim izborima

- fazu konsolidacije najvećih stranaka na političkoj sceni

- $\quad$ „dječje» bolesti koalicijskih odnosa

- $\quad$ porasta apatije kod birača

- trenda slabljenja identifikacije sa strankama i, povezano s time, gubitka stranačkog članstva - profesionalizacije vodstva najvećih stranaka

- podržavljenje financiranja stranaka prema izbornim rezultatima, što pogoduje jačanju jakih i slabljenju slabih stranaka

Od trendova koje treba očekivati u narednom periodu, a koji su dio procesa razvijenih demokracija u svijetu, jesu trend slabljenja ideološke orijentacije stranaka na lijeve i desne te trend daljnje transformacije stranaka prema profesionaliziranim biračkim strankama. Politička komunikacija je uglavnom posredovana komunikacija prenošena medijima masovne komunikacije. Druge oblike komunikacije, poput interne komunikacije i sl., nismo istraživali. Izbor vrste $\mathrm{i}$ podvrste političke komunikacije preko medija masovnih komunikacija u korelaciji je sa trendovima koji zahvaćaju političke stranke. Ukoliko npr. programi političkih stranaka više konvergiraju, izbor vrste političke komunikacije više će se oslanjati na politički imidž i personalizirani tip izborne kampanje. Obrnuto, različiti programi političkih stranaka stavit će težište na sadržajnu komponentu i racionalan izbor.

\section{Ciljevi istraživanja}

- utvrditi postoji li korelacija između medijske zastupljenosti pojedinih političkih opcija i osoba i izbornog ponašanja (izbornih rezultata)

- analizom sadržaja tiskovnih objava utvrditi na koji su način predstavljene političke opcije u tiskovnim medijima, koje su bile glavne teme predizborne kampanje te jesu li su političke stranke i pojedinci bili ravnopravno zastupljeni $\mathrm{u}$ tiskovnim medijima. /8/

- utvrditi jesu li sredstva stranaka i pojedinaca utrošena $u$ propagandnu kampanju $u$ korelaciji s izbornim ponašanjem, odnosno rezultatima.

\section{Metodologija, metode i vremeske granice istraživanja}

Istraživanje je provođeno $\mathrm{u}$ razdoblju od 1 . rujna do 30. studenoga 2003. godine.

Osnovna metoda istraživanja koja je korištena bila je analiza sadržaja, što je rezultat zahtjeva ciljeva istraživanja za objektivnim, sustavnim i kvantitativnim načinom ispitivanja sadržaja komunikacije te udovoljavanju zahtjevima postavljenih ciljeva.

Istraživanje je provođeno na dvije razine:

a/ analiza medijskih objava obuhvaćala je cjelokupan sadržaj tiskovina u Republici Hrvatskoj u periodu provođenja istraživanja.

b/ analiza propagandnih spotova obuhvatila je tri medija, i to: cjelokupan hrvatski tisak, cjelokupan nacionalni TV program i sve propagandne spotove na vanjskim površinama /9/ u promatranom razdoblju.

\subsection{Jedinica analize sadržaja}

Jedinica analize bila je svaka novinska objava u kojoj je čitavim svojim sadržajem ili samo jednim njenim dijelom bio obuhvaćen 1 od 75 subjekata iz sfere političkih stranaka ili osoba unutar pojedinih političkih opcija. Jedinica analize $u$ segmentu oglasa bio je svaki objavljeni oglas na televiziji, na vanjskim površinama i u tisku. Prilikom definiranja elemenata nacrta istraživanja u lipnju 2003. godine bila je predviđena i analiza sadržaja informativnog programa nacionalnih TV postaja sa kojom se i započelo u rujnu 2003. Međutim, prilikom donošenja Pravila bilo je vidljivo da će svaka politička opcija u emisijama HTV-a dobiti jednaku količinu vremena, pa se od ovog dijela analize odustalo tijekom listopada.

\subsection{Opseg analize}

Analizom je obuhvaćen sav hrvatski tisak $u$ periodu istraživanja, što je ukupno 257 tiskovina tijekom jednog mjeseca istraživanja. 
Analizom tiskovina obuhvaćena su sva izdanja novina u Hrvatskoj čija je tiraža veća od 4000 primjeraka, a pregled i odabir sadržaja obuhvatili su cijelu novinu. Analizom sadržaja obuhvaćeno je ukupno 159.258 novinskih stranica.

U oglasnom dijelu analize opseg je bio sljedeći: 1. Sve TV postaje nacionalne koncesije/dosega, i to sva tri programa HTV-a i Nova TV koji su snimani dvadeset i četiri sata dnevno, za vrijeme tri mjeseca istraživanja; reklame koje su se odnosile na predizbornu kampanju selektirane su i obrađene kroz analitičku matricu. Ukupno su selektirane 47.382 reklame, od čega se njih 1466 odnosi na političke stranke. Pregledano je ukupno 6480 sati programa.

2. Istraživanjem su obuhvaćene sve tiskovine u Republici Hrvatskoj kako bi se prvo izvršila selekcija svih reklama, a zatim selekcija reklama političkih stranaka $\mathrm{u}$ periodu od tri mjeseca. Analizom sadržaja obuhvaćeno je ukupno 159.258 novinskih stranica; selektirano je 39.216 tiskovnih oglasa, od čega se na političke stranke odnosi 1225 oglasa.

3. Podaci o reklamama na vanjskim površinama dobiveni su susretljivošću agencija.

\subsection{Kategorizacija}

Analitička matrica sastojala se od kvantitativne (formalne) i sadržajne analize./10/

a/ za tiskovine

Čestice kvantitativne analize:

- novina

- datum

- $\quad$ stranica

- $\quad$ izdanje

- $\quad$ smještaj na stranici

- površina objave

- $\quad$ vrijednost objave (prema prosječnom cjeniku oglasnog prostora)

Čestice sadržajne analize:

- naslov objave

- $\quad$ autor objave

- Z žanr objave/11/

- $\quad$ sadržaj objave (puni tekst)

- politička stranka

- osoba
- $\quad$ stav autora prema subjektu (stranci ili osobi/ političaru)

- orijentacija sadržaja, i to osmostruka od izrazito pozitivne do izrazito negativne objave

- status subjekta (stranke ili osobe) u odnosu na vrstu objave (od objave punog sadržaja do objave u kojoj je subjekt samo spomenut (peterostruka gradacija)

- $\quad$ tema poruke objave

Protokol analize sadržaja objava bio je sljedeći: jedan grupa analitičara selektirala je, nakon pregleda cjelokupnog tiska, objave koje se odnose na političke stranke i osobe iz političkog života; druga grupa analitičara referencirala je objave prema gore navedenim česticama analize, a valorizaciju je svakoj fazi produkcije obavljao posebno osposobljen tim analitičara. b/ za oglase

Čestice kvantitativne analize za tiskovni dio:

- novina

- datum

- $\quad$ stranica

- $\quad$ izdanje novina

- $\quad$ veličina oglasa

Čestice sadržajne analize za tiskovni dio:

- poruka oglasa

- vrijednost oglasa prema stvarnom cjeniku oglasnog prostora tiskovine koja se analizira

- $\quad$ oglas u boji ili crno-bijeli

- $\quad$ naručitelj oglasa - stranka ili osoba

Čestice kvantitativne analize propagandnih poruka za televizijski dio:

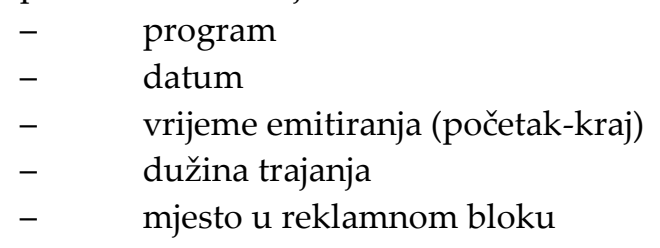

Čestice sadržajne analize propagandnih poruka za televizijski dio:

- poruka oglasa

- vrijednost oglasa prema stvarnom cjeniku oglasnog prostora u vremenu i danu emitiranja 
- $\quad$ naručitelj oglasa - stranka ili osoba

I ovdje je protokol analize sadržaja obavljen u tri kruga, pri čemu je validnost provjeravana $u$ dodatna dva kruga.

\section{Klasifikacije sadržajne analize}

U ovoj analizi sadržaja političkom strankom smatramo svaku političku stranku registriranu pri Ministarstvu pravosuđa Republike Hrvatske u vrijeme provođenja istraživanja, točnije trenutku početka provođenja istraživanja.

Kao osobe $\mathrm{u}$ političkim strankama $\mathrm{u}$ matricu analize uključili smo sve zastupnike u Saboru $\mathrm{RH}$, kao i vodeće političke osobe $\mathrm{u}$ trenutku početka istraživanja (predsjednike neparlamentarnih stranaka).

\subsection{Subjekti analize}

Sve političke stranke i postojeći saborski zastupnici bili su u matrici istraživanja razvrstani pod subjekte analize (ukupno 206 subjekata).

\subsection{Sadržajne skupine}

Analitička matrica sadržajnih skupina postavljena je hijerarhijski, pri čemu je sadržaj medijske objave mogao biti razvrstan $u$ više tematskih cjelina ukoliko se odnosio na više tema. Cilj ovog dijela matrice istraživanja bio je, u korelaciji sa strankom i osobom iz stranke, pružiti informacije o temeljnim temama kampanje po pojedinim strankama. Teme rasprave uključivane su u matricu u trenucima kada su ih akteri (subjekti) počeli promovirati u medijima, a nakon obrade razvrstane su 14 tematskih skupina koje su se najčešće pojavljivale u medijskim nastupima.

\section{Osnovni rezultati istraživanja}

Ograničenost prostora ne omogućava nam predstavljanje svih glavnih nalaza pa smo $u$ skraćenoj verziji nastojali prezentirati glavne nalaze istraživanja koji će pokušati odgovoriti na postavljene ciljeve.

\subsection{Zastupljenost objava o političkim strankama/osobama po novinama}

Od 1.9. do 30.11.2003. objavljeno je ukupno 21.963 članka na zadane čestice analize/politička stranka ili osoba.

Najviše članaka, od ukupnog broja članaka, objavio je Vjesnik, a slijede Večernji list, Jutarnji list i Slobodna Dalmacija.

\subsection{Odnos ukupne površine novina i} površine članaka o političkim strankama

Ovaj odnos neizravno ukazuje na uređivačku koncepciju tiskovina te se između dnevnih informativno- političkih tiskovina i tjednih informativno-političkih izdanja ne uočava bitna razlika u tretiranju tematike izbora.

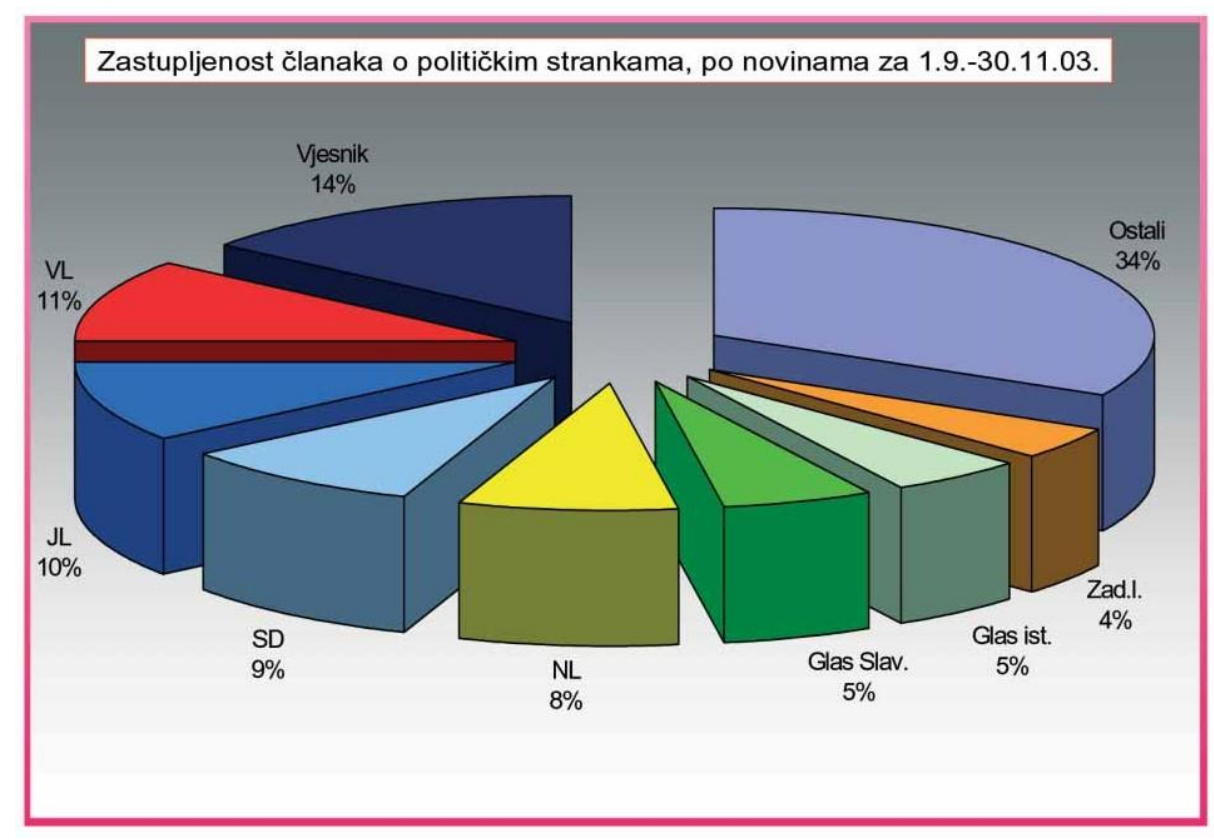




\section{POVRŠINA ČLANAKA O IZBORIMA U ODNOSU NA UKUPNU POVRŠINU NOVINA}

\begin{tabular}{|l|c|l|l|}
\hline $\begin{array}{l}\text { Naziv } \\
\text { tiskovine }\end{array}$ & $\begin{array}{l}\text { Površina novina } \\
\text { posvećena izborima (\%) }\end{array}$ & $\begin{array}{l}\text { Naziv } \\
\text { tiskovine }\end{array}$ & $\begin{array}{l}\text { Površine } \\
\text { novina } \\
\text { posvećena } \\
\text { izborima (\%) }\end{array}$ \\
\hline Globus & 26,50 & Jutarnji list & 10,86 \\
Fokus & 25,00 & Slobodna D. & 10,90 \\
Feral Tribune & 23,30 & Novi list & 10,70 \\
Nacional & 22,60 & Večernji list & 9,24 \\
Hrvatska ljevica & 21,90 & Zadarski list & 9,70 \\
Posavska Hrvatska & 21,40 & Glas istre & 9,60 \\
Hrvatsko slovo & 20,20 & Vjesnik & 9,50 \\
Poslovni tjednik & 17,20 & Glas Slavonije & 7,80 \\
\hline \multicolumn{2}{|c|}{ Razdoblje: 1.9.-30.11.2003. } & \multicolumn{2}{|c|}{ Razdoblje: 1.9.-30.11.2003. }
\end{tabular}

\subsection{Zastupljenost subjekata i stav autora objave prema subjektima}

Formalna zastupljenost pojedinih subjekata analize prezentirana je u sljedećem grafikonu. Ona istovremeno nije i jednoznačni pokazatelj naklonjenosti medija prema pojedinoj političkoj opciji jer su kvantificirani rezultati istovremeno i rezultat medijskog praćenja predizbornih događanja. Političke stranke i subjekti su sa više ili manje uspjeha nastojali inscenirati događaje tako da oni budu medijski prihvatljivi za objavu pa je i količina objava zasigurno ovisila o vještini, znanju i općenito sposobnosti izbornih stožera da upravljaju informacijama.

Pod orijentacijom se $u$ ovome radu podrazumijeva (ne)naklonjenost novinara tretmanu određene političke opcije ili osobe. Obzirom da je većina događanja bila inicirana od strane političkih stranaka, i novinarske interpretacije događanja bile su uglavnom, $\mathrm{u}$ žanrovskom smislu, izvještajnog karaktera.
Korektno izvještavanje o događajima ne može uključivati drugu orijentaciju osim neutralne/12/, iako sam izbor vijesti o pojedinom događaju ovisi o stavu novinara i može samom događaju davati drukčiju intonaciju. Zbog toga u rezultatima istraživanja imamo većinom neutralne medijske objave. Kvalitativna analiza sadržaja članka na primjeru jednog događaja kod raznih novina dala bi odgovore i o moguće različito intoniranim događajima, ali ne i vrijednosni sud ukoliko je izvještaj u žanrovskom smislu prenesen korektno. (To se odnosi na crticu, vijest i izvještaj, ali ne i na izvještaj sa osvrtom, komentarom koji je $\mathrm{u}$ analizi posebno tretiran.) Peterostruka orijentacija dovoljno je široki okvir za prikaz stava prema pojedinim političkim opcijama. Najviše negativnih objava imali su I. Jakovčić, Dražen Budiša i Vesna Pusić, a najviše pozitivnih Ivo Sanader i Ante Đapić. 

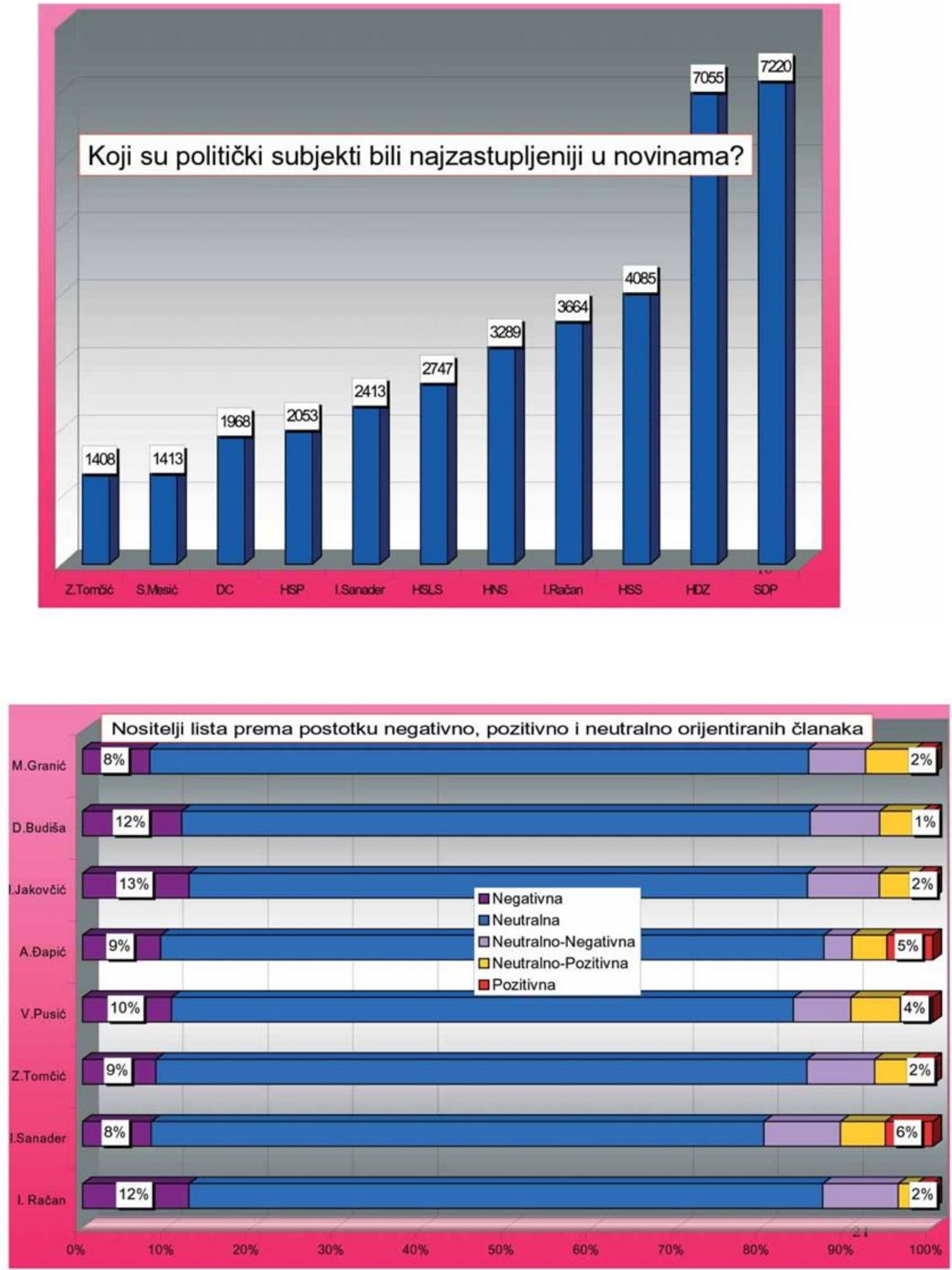

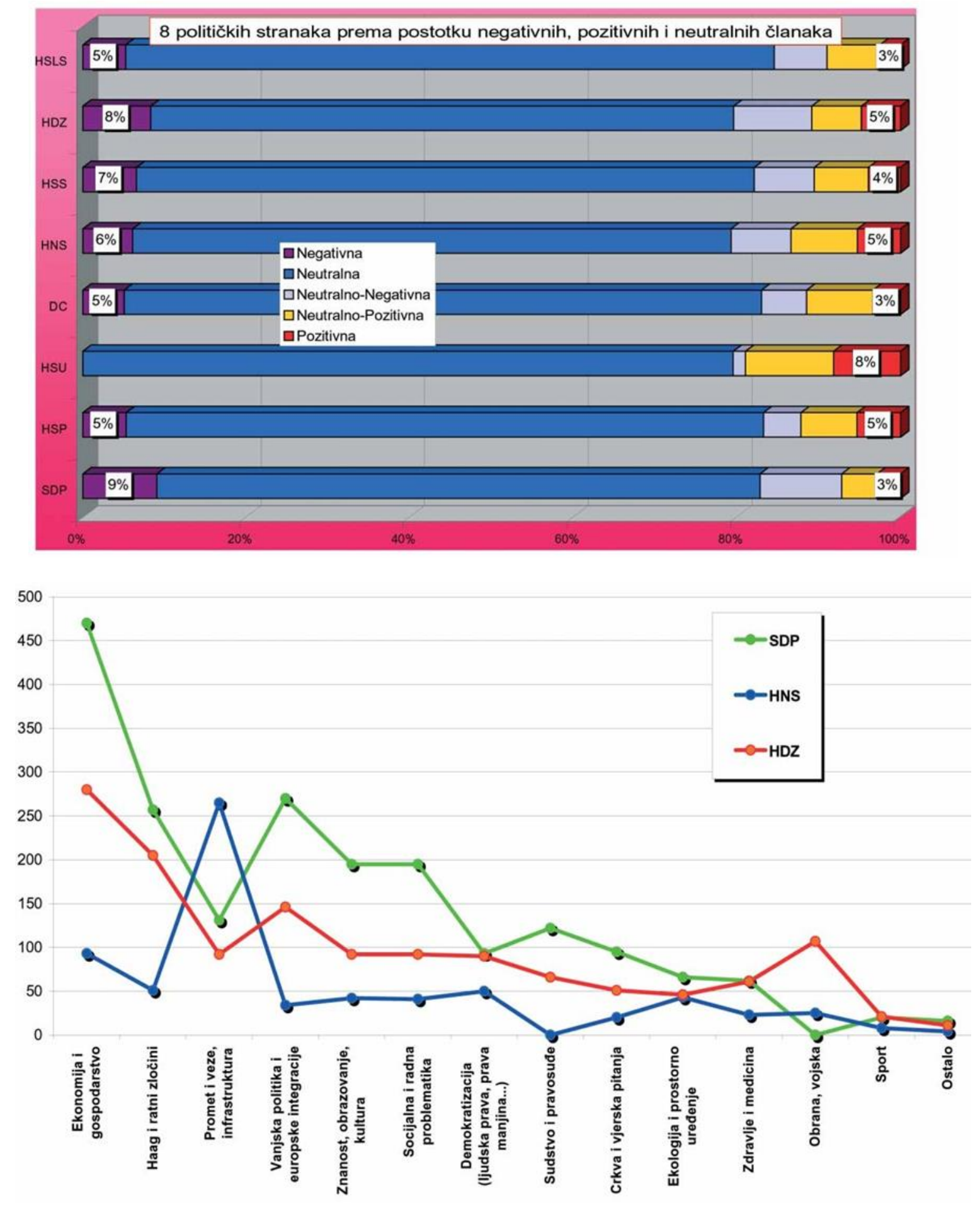

Najviše negativnih objava kod političkih stranaka imaju SDP, HDZ i HSS, a najviše pozitivnih HSU, HDZ i HNS. 


\subsection{Teme rasprave}

Utjecaj medija na aktualnost pojedinih tema bio je predmetom mnogih istraživanja o odnosu između javnog mnijenja (public agenda), izbora i tretiranja društvenih tema i događaja koje obrađuju mediji i tema političkih stranaka. /13/

Odnos između percepcije stvarnih društvenih problema (javnomnijenjska percepcija), percepcije društvenih problema i tema koje nameću mediji te onoga što političke stranke percipiraju u svojim programima $\mathrm{i}$ šire $\mathrm{kroz}$ razne komunikacijske kanale do javnosti - nije istoznačan.

- gospodarski problemi su temeljna preokupacija stanovništva/javnog mnijenja/14/,

- odnos prema Europi i Haagu je u vremenu provođenja analize bila jedna od temeljnih medijskih preokupacija

- političke teme različito su raspodijeljene po pojedinim političkim opcijama i većinom nisu usuglašene $\mathrm{s}$ javnom $\mathrm{i}$ medijskom agendom.

\begin{tabular}{|c|c|c|c|}
\hline Izbori 2003. & SDP & HNS & HDZ \\
\hline Teme rasprave & Rang & Rang & Rang \\
\hline Ekonomija i gospodarstvo & 1 & 2 & 1 \\
\hline Haag i ratni zločini & 3 & 3 & 2 \\
\hline Promet i veze, infrastruktura & 6 & 1 & 5 \\
\hline Vanjska politika i europske integracije & 2 & 8 & 3 \\
\hline Znanost, obrazovanje, kultura & 4 & 6 & 6 \\
\hline Socijalna i radna problematika & 5 & 7 & 7 \\
\hline Demokratizacija (ljudska prava, prava manjina...) & 9 & 4 & 8 \\
\hline Sudstvo i pravosuđe & 7 & 14 & 9 \\
\hline Crkva i vjerska pitanja & 8 & 11 & 11 \\
\hline Ekologija i prostorno uređenje & 10 & 5 & 12 \\
\hline Zdravlje i medicina & 11 & 10 & 10 \\
\hline Obrana, vojska & 14 & 9 & 4 \\
\hline Sport & 12 & 12 & 13 \\
\hline Ostalo & 13 & 13 & 14 \\
\hline
\end{tabular}




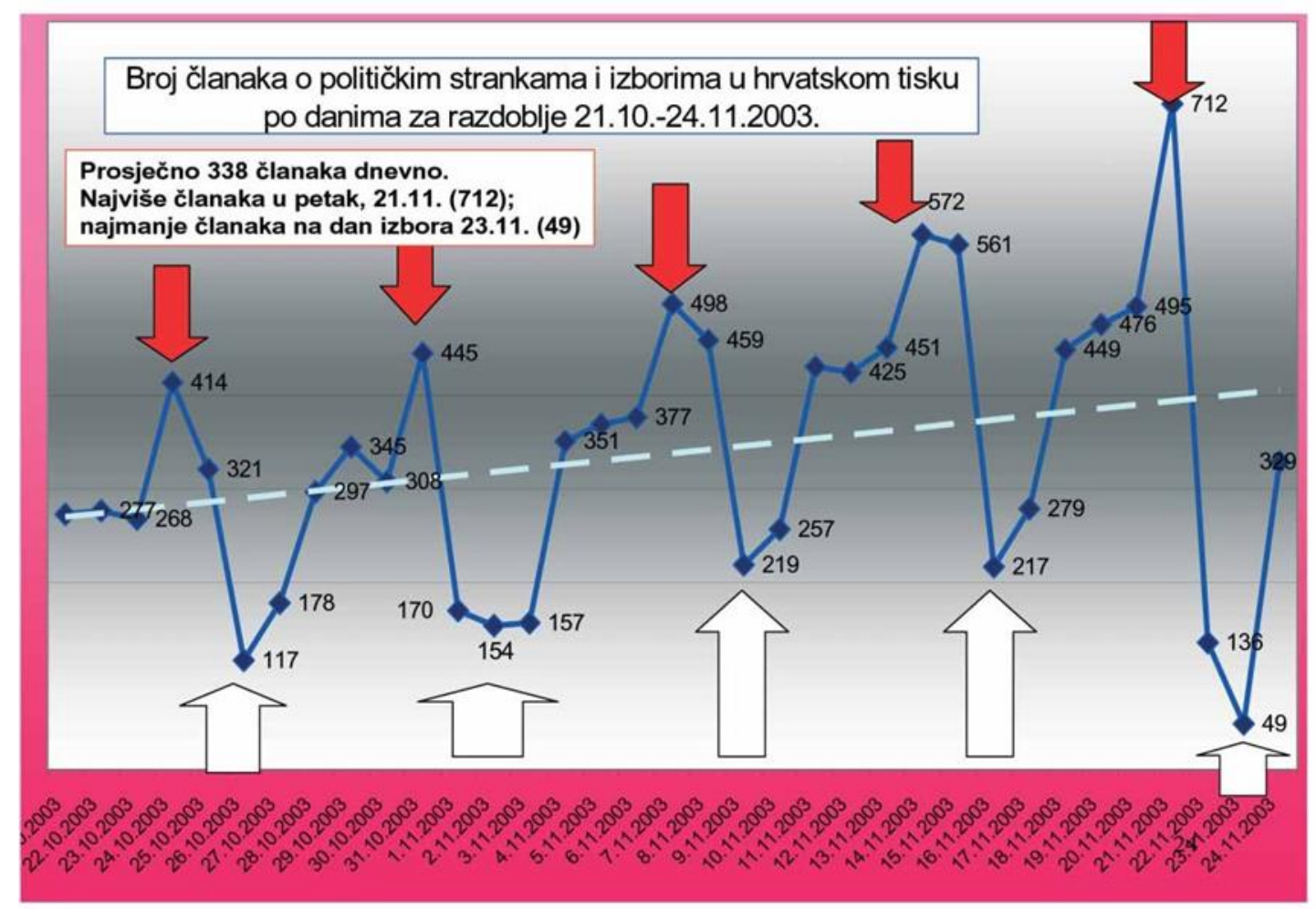

\subsection{Frekvencija objava}

Prilikom razmatranja medijskih tema usmjerenih prema javnosti važni su podaci iznesenih istraživanja o vremenskom utjecaju tema nametnutih javnom mnijenju.

Podaci iz Fanovog istraživanja, o utjecaju poruka koji eksponencijalno pada nakon 24 sata, ukazuju na važnost pravilnog tempiranja upućivanja poruka preko medija.

Podaci ukazuju na trend rasta broja poruka bliženjem dana izborne šutnje i njihov najveći broj uoči dana izborne šutnje. Obzirom da je, uz medijsku objavu, i propagandni oglas oblik komunikacije prema javnosti, dajemo i prikaz rasta broja propagandnih poruka.

Podaci također ukazuju na poznavanje dnevne čitanosti tiskovina, obzirom da je većina medijskih objava i propagandnih oglasa upućena $\mathrm{u}$ dane kad tiskovine imaju najveću nakladu.

Izdvojili smo dvije najveće stranke da bismo vidjeli postoji li razlika $u$ frekvenciji pojavljivanja tijekom promatranog razdoblja. Frekvencija medijskih objava kod svih stanaka, osim u slučaju HSU, pokazuje uzlazni trend i kulminaciju uoči izbora. 

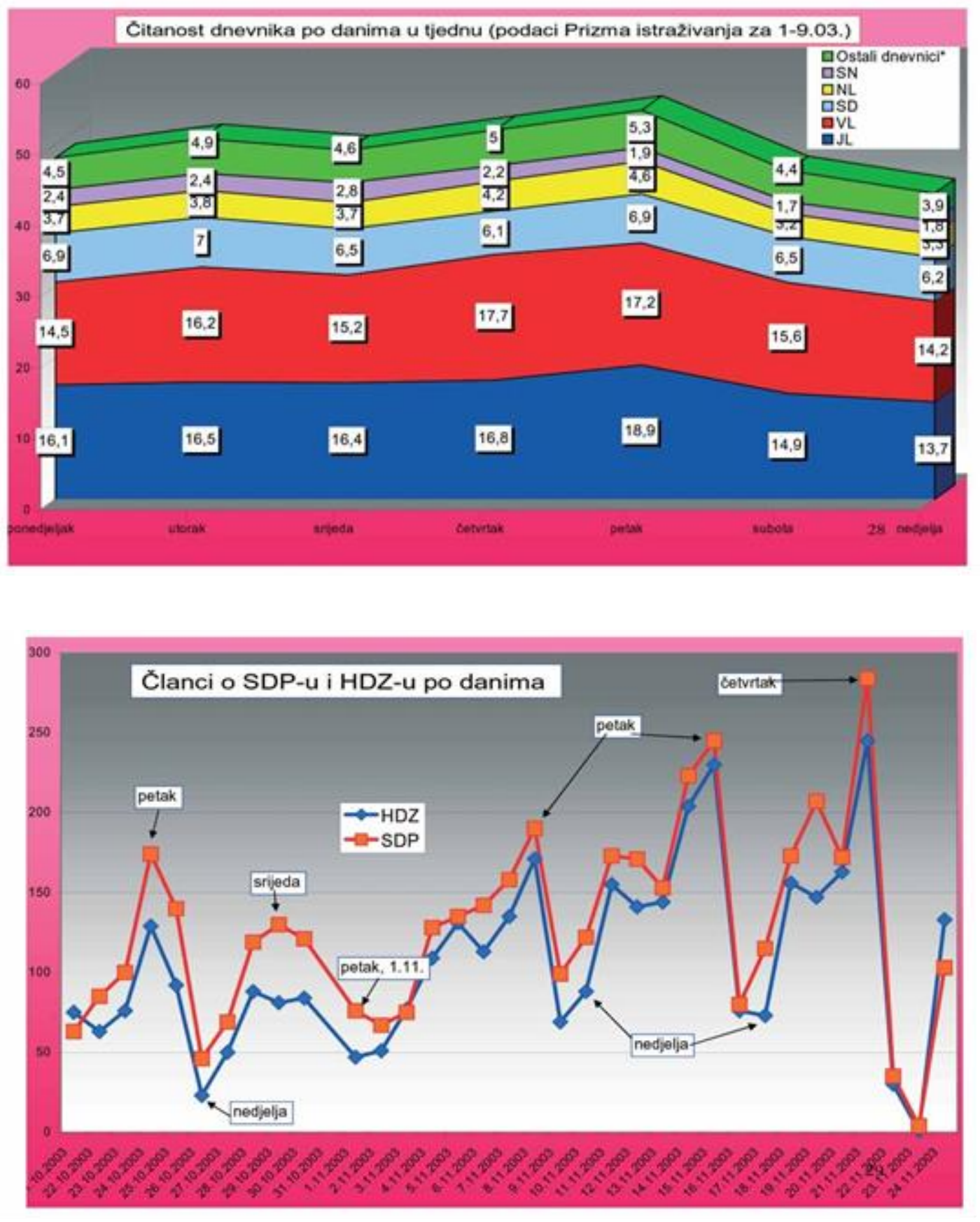

6. 6. Tiskovine i orijentacija objava prema glavnim političkim subjektima

Rezultati istraživanja potvrdili su statistički zanemarivu razliku u tretmanu pojedinih političkih opcija kod dnevnih informativno-političkih novina. Statistički zanemariva razlika u tretmanu potvrđuje već iznesenu tezu da dnevna informativnopolitička tiskovna glasila nisu politički profilirana prema određenoj političkoj opciji.
Pretpostavljali smo da ćemo u Večernjem listu i Slobodnoj Dalmaciji naći više medijskih objava koje su naklonjene tzv. desnom centru i političkim opcijama koje taj centar predstavljaju, a kod Jutarnjeg lista više objava naklonjenih centru i lijevom centru, ali nismo pronašli statistički značajnu razliku.

Kod informativno-političkih tjednika nacionalne distribucije uočili smo statistički značajniju razliku, i to kod Globusa, Nacionala i Hrvatskog narodnog lista. 


\subsection{Medijska zastupljenosti i izborni rezultati} U nastavku donosimo osnovne rezultate istraživanja:

Da bismo odgovorili na jedan od postavljenih ciljeva istraživanja, o korelaciji između medijske zastupljenosti i izbornog ponašanja, morali smo u model uvrstiti i podatke o javnomnijenjskom istraživanju predizbornog raspoloženja birača prije početka službene predizborne kampanje. Obzirom da ne raspolažemo dnevnim podacima javnomnijenjskog istraživanja raspoloženja birača koji bi se podudarali sa početkom analize sadržaja medijskih objava (1.9. 2003.godine), bili smo prisiljeni upotrijebiti podatke IRI-jevog istraživanja koje je provođeno od 8. do 29. rujna. Pretpostavljamo da taj vremenski nesklad ne bi bitno utjecao na rezultate istraživanja.

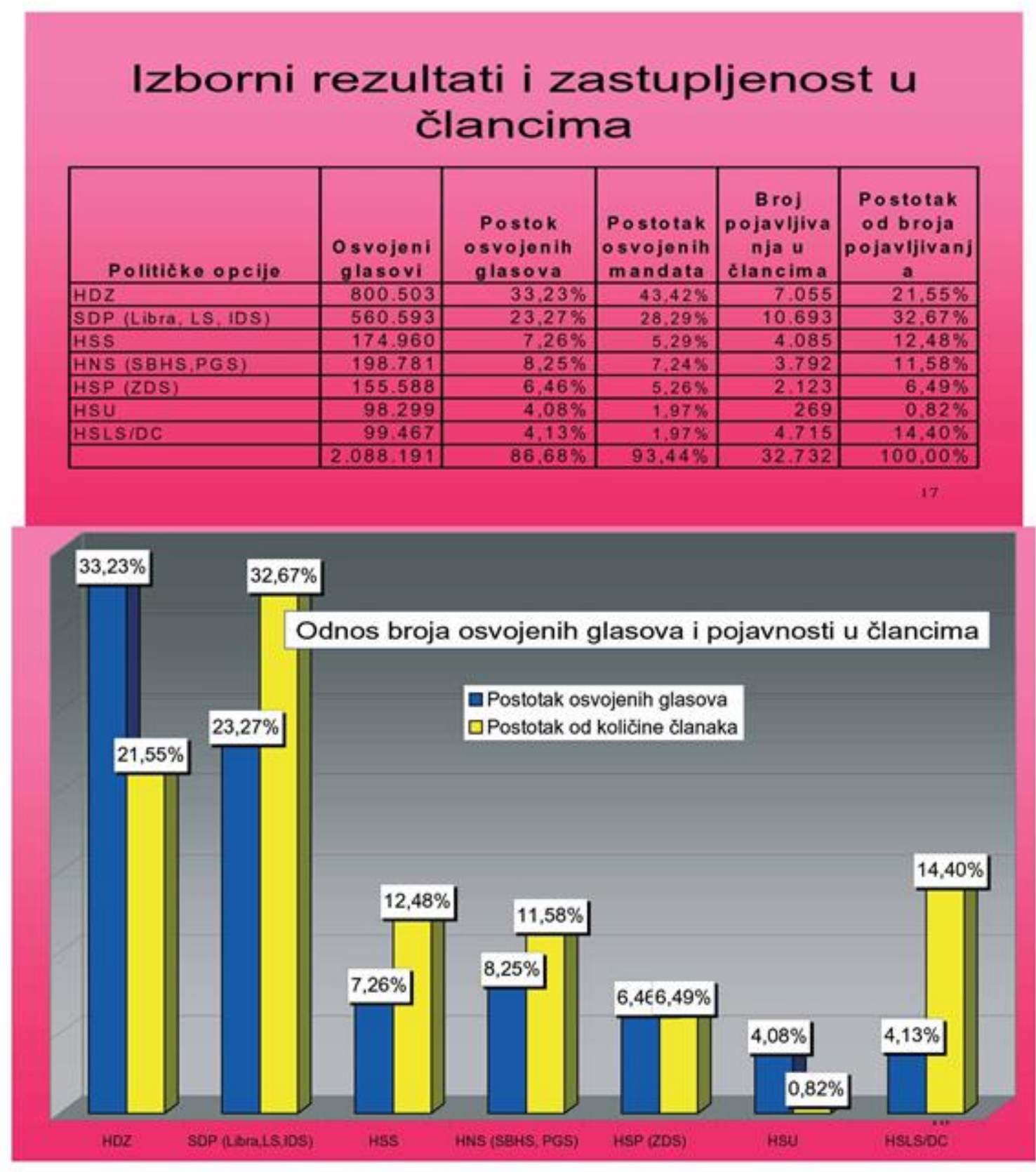

Osnovni nalaz istraživanja dajemo u sljedećoj tablici: 


\begin{tabular}{|c|c|c|c|c|c|}
\hline Stranke & $\begin{array}{c}\text { Istraživanje } \\
\text { javnog } \\
\text { mnijenja }\end{array}$ & $\begin{array}{l}\text { Osvojeni } \\
\text { glasovi }\end{array}$ & $\begin{array}{c}\text { Medijska zastupljenost } \\
\text { u tiskovinama }\end{array}$ & $\begin{array}{c}\text { Broj } \\
\text { osvojenih } \\
\text { glasova }\end{array}$ & $\begin{array}{c}\text { Broj } \\
\text { medijskih } \\
\text { objava }\end{array}$ \\
\hline 1 & 2 & 3 & 4 & 5 & 6 \\
\hline $\mathrm{HDZ}$ & 28 & $33,23 \%$ & $21,55 \%$ & 800.503 & 7055 \\
\hline SDP (Libra,LS,IDS) & 23 & $23,27 \%$ & $32,67 \%$ & 560.593 & 10.693 \\
\hline HSS & 11 & $7,26 \%$ & $12,48 \%$ & 174.960 & 4085 \\
\hline HNS (SBHS, PGS) & 8 & $8,25 \%$ & $11,58 \%$ & 198.781 & 3792 \\
\hline HSP (ZDS) & 5 & $6,46 \%$ & $6,49 \%$ & 155.588 & 2123 \\
\hline HSU & 0 & $4,08 \%$ & $0,82 \%$ & 98.299 & 269 \\
\hline HSLS/DC & 9 & $4,13 \%$ & $14,40 \%$ & 99.467 & 4715 \\
\hline Ostali & 7 & & & & \\
\hline neodlučni & 9 & & & & \\
\hline Ukupno & 100 & $86,68 \%$ & $99,99 \%$ & 2.088 .191 & 32.732 \\
\hline
\end{tabular}

Postotci u drugom stupcu rezultat su javnomnijenjskog istraživanja koje je za potrebe IRI-ja provela agencija PULS $u$ razdoblju od 8 . do 29. rujna. Ispitivanje je provedeno metodom osobnog intervjua $u$ kućanstvu ispitanika, i to na uzorku od 4000 građana starijih od 18 godina. Korišten je dvoetapno stratificirani slučajni uzorak, a kod pitanja o stranačkim preferencijama korištena je metoda tajnog izjašnjavanja./15/

U trećem stupci prikazani su postoci osvojenih glasova prema rezultatima Izborne komisije i to prije konačne raspodjele mandata (preraspodjela na osnovu stranaka koje nisu prošle izborni prag).

U četvrtom stupcu dali smo postotak medijske zastupljenosti stranaka u tiskovinama.

Uspoređujući postotak glasova koje bi stranke dobile da su izbori održani prije samog početka službene kampanje (prema istraživanju javnog mijenja) $\mathrm{s}$ konačnimpostotkomdobivenihglasova,uzevšip ritome $\mathrm{u}$ obzir da se $\mathrm{u}$ međuvremenu dogodila predizborna kampanja, odnosno da su pojedine političke opcije imale određenu medijsku zastupljenost izraženu kao broj objava o pojedinoj političkoj opciji, pretpostavili smo da možemo zaključivati o generalnom i pojedinačnom značaju i smjeru utjecaja zastupljenosti u medijima na konačan postotak broja osvojenih glasova.

Naše temeljne pretpostavke bile su:
1. Ako je pojedinačna razlika u postotku glasova prije i poslije kampanje značajna (bez obzira na smjer), kampanja (pojavljivanje $u$ medijima) je utjecala na izborne rezultate

2. Ako postoji korelacija između postotka glasova koje bi stranke dobile prije kampanje i konačnog postotka osvojenih glasova, zastupljenost $u$ medijima nije više ili manje linearne sukladnosti $u$ variranju), a zastupljenost $\mathrm{u}$ medijima je $\mathrm{u}$ jednakom omjeru

djelovalanapovećanjeilismanjenjekonačnogudj elau glasovima svih stranaka, možemo zaključiti da među njima postoji uzročnoposljedična veza, odnosno da je zastupljenost $u$ medijima izravno utjecala na promjene stava javnosti tijekom predizborne kampanje.

\section{ISTRAŽIVAČKI REZULTATI}

1. Pojedinačne razlike među postocima glasova prije i poslije: SDP (Libra, LS, IDS), HNS i HSP ne bilježe značajnu razliku $u$ promjeni udjela glasova; HSS i HSLS/DC bilježe značajan pad $\mathrm{u}$ postotku glasova nakon provedene kampanje; HDZ je jedina stranka koja bilježi značajan porast udjela glasova nakon kampanje. HSU je $u$ ovom dijelu specifična, jer $u$ javnom mnijenju prije kampanje nije participirala kao ravnopravna stranka, a nakon kampanje je osvojila velikih $4 \%$ te nakon raspodjele mandata postala parlamentarna stranka.

2. Opseg kampanje mjeren kroz medijsku zastupljenost stranaka varira $\mathrm{u}$ rasponu od 
0,82\% (za HSU) do 32,67\% (za SDP) i nikako ne predstavlja stabilnu i sustavnu varijablu koja bi na isti način i $\mathrm{u}$ istom smjeru utjecala na ukupan udio osvojenih glasova.

3. Obzirom da korelacije između udjela glasova prije kampanje i udjela medijskih objava $(\varrho=0,61, \quad \mathrm{p}>0,01) / 16 /$ te korelacije između udjela medijskih objava i postotka dobivenih izbornih glasova ( $\mathrm{Q}=0.71, \mathrm{p}>0.01$ ) nema, možemo zaključiti da broj medijskih objava nije $\mathrm{u}$ izravnoj vezi $\mathrm{s}$ rejtingom stranaka prije početka kampanje, niti je povezan s konačnim izbornim rezultatom.

4. Ne postoji sustavan omjer između zastupljenosti u medijima i konačnog izbornog rezultata na osnovu kojeg bismo mogli utvrditi da su ove dvije pojave u uzročno-posljedičnoj vezi.

Provjerom prve hipoteze utvrdili smo da kampanja u cijelosti, kao ni udio medijskih pojavljivanja, nije znatno utjecala na konačni izborni rezultat, jer se udio glasova, općenito gledajući, za stranke nije značajno promijenio nakon predizborne kampanje.

Stranke imaju relativno stabilno biračko tijelo čiji stavovi nisu podložni bombardiranju predizbornim informacijama $\mathrm{u}$ medijima, $\mathrm{o}$ čemu svjedoče i rezultati predizbornog raspoloženja birača, prema kojima je gotovo dvije trećine birača ustvrdilo kako je vjerojatnost da na njihovu odluku utječe predizborna kampanja mala./17/

Nakon kampanje dogodili su se određeni pomaci u promjeni udjela glasača, ali općenito gledajući, ne značajno.

$9 \%$ neopredijeljenih birača utjecalo je na konačne rezultate glasanja.

\subsection{Propagandne poruke}

\subsubsection{Vrste propagandnih poruka}

»Komunikacijsko je djelovanje» (a propagandne poruke svakako spadaju $u$ oblik komunikacijskog djelovanja) je "složeni, kontinuiran interakcijski proces $\mathrm{u}$ kojem komunikator pokušava utjecati na komunikacijskog partnera kako bi ovaj prihvatio predložene stavove $i$ obrasce ponašanja»/18/ s ciljem uvjeravanja primatelja kako poruka ima općeprihvaćen društveni značaj. »Poruka sadrži »koncenzualnu validnost» (odobrenje stranke, skupine ili društva). Pošiljatelj pokazuje primatelju kakva ga društvena »nagrada» očekuje ako preuzme poručiteljev cilj, te kakve posljedice može očekivati ako ga ne prihvati»/19/ Možda najbolju podjelu vrsta propagandnih poruka prema namjeri pošiljatelja treba potražiti $u$ Aristotelu koji u Vještini retorike govori o pojmu vjerovanja (etos), drugim oblicima dokaza, poput emocionalnog poziva (patos) i samoj poruci, govoru i njegovoj racionalnosti (logos). Etos je pri tome u samom diskursu i donosi uvid u značaj govornika, u njegov integritet i dobru volju.Obzirom na naglašenu kompeticiju u predizborno vrijeme kampanje su najčešće dijele na pozitivne i negativne, pri čemu se često kombiniraju elementi jedne i druge kampanje. Iz ove podjele treba izdvojiti tzv. prljavu kampanju, a njeni oblici manifestiranja su: tretiranje političkog suparnika kao neprijatelja, sa svim konotacijama koje takav status nosi /20/,

isticanje atributa vlastite stranke koji impliciraju negativne atribute neprijatelja $\mathrm{i} / \mathrm{ili}$ direktno naglašavanje »negativnih» atributa neprijatelja (karakterizacija poput: državotvorna stranka, antikomunistička stranka, jedina demokratska opcija, stranka opasnih namjera) ima za cilj polarizaciju političke scene i javnog mnijenja, kao i homogenizaciju vlastitih redova

Negativne spotove moguće je podijeliti i kao:/21/

opće negativne spotove tzv. flip-flop spotove - »ovdje se radi o navođenju obećanja uoči prošlih izbora i onoga što je stvarno učinjeno»/22/

usporedne i kontrastne spotove; ovdje se ne radi toliko o neposrednom napadu na protivnika, koliko o uspoređivanju prednosti svojeg kandidata i nedostataka suparnika spotove neobavljenog posla; prikaz situacija $u$ kojima su određeni pojedinac ili stranka trebali djelovati,

a nisu spotove »negativnog protiv pozitivnog»; u posljednje vrijeme došlo se do spoznaje da se i protivnički propagandni spotovi mogu napasti i prikazati da je ono što druga strana 
navodi kao pozitivno i uspjeh, zapravo obmanjivanje i laž

spotove tipa »napadni i bježi»; »spotovi koji se emitiraju u posljednji trenutak, tako da je protivniku otežano, ako ne i onemogućeno, odgovoriti..»/23/

\subsection{Osnovni nalazi istraživanja}

\subsubsection{Sadržaj i broj propagandnih poruka po strankama i medijima}

\begin{tabular}{|c|c|}
\hline \multicolumn{2}{|l|}{ TELEVIZIJA } \\
\hline STRANKA & IZBORNA PORUKA \\
\hline \multirow[t]{2}{*}{ HDZ } & POKRENIMO HRVATSKU \\
\hline & $\begin{array}{l}\text { PORUKE IZ EUROPE - SANADER SA } \\
\text { EUROPSKIM DUŽNOSNICIMA - IZJAVE ANGELE MERKEL, PREDSJEDNICE CDU-A, SCHUSSELA, } \\
\text { AUSTRIJSKOG KANCELARA I EDMUNDA STOIBERA, PREDSJEDNIKA VLADE BAVARSKE }\end{array}$ \\
\hline \multirow[t]{2}{*}{ HNS } & ZA HNS - ONI SU MANJE ISTI \\
\hline & GRADIMO BUDUĆNOST ZAJEDNO \\
\hline \multirow[t]{2}{*}{ IHSLS I DC } & $\begin{array}{l}\text { IVRATIT ĆEMO OSMJEH NA } \\
\text { iSLAVONIJE }\end{array}$ \\
\hline & INOVA SNAGA ZA BOLJU HRVATSKU \\
\hline \multirow[t]{2}{*}{ İHSP } & $\begin{array}{l}\text { IVJERUJ U SEBE - HRVATSKI, SVJESNI, } \\
\text { PRAVEDNI }\end{array}$ \\
\hline & $\begin{array}{l}\text { VJERUJTE U SEBE - MISLITE EUROPSKI, } \\
\text { BIRAJTE HRVATSKI }\end{array}$ \\
\hline HSS & IVOLIM SVOJU ZEMLJU \\
\hline \multirow[t]{4}{*}{ SDP } & DA ZA SDP - DA ZA OBITELJ \\
\hline & $\begin{array}{l}\text { DA ZA SDP - DA ZA HRVATSKU } \\
\text { DA ZA SDP - DA ZA OBRAZOVANIE }\end{array}$ \\
\hline & DA ZA SDP - DA ZA RAZVOJ \\
\hline & $\begin{array}{l}\text { DA ZA SDP - DA ZA BUDUĆNOST } \\
\text { tDA ZA SDP - DA ZA SIGURNOST } \\
\text { iDA ZA SDP - DA ZA ZAPOSLJAVANIE } \\
\text { iDA ZA ZA }\end{array}$ \\
\hline SNS & SIGURNI U SEBE \\
\hline \multicolumn{2}{|l|}{ OUTDOOR } \\
\hline STRANKA & IZBORNA PORUKA \\
\hline \multirow[t]{3}{*}{$\mathrm{HDZ}$} & POKRENIMO HRVATSKU \\
\hline & 3. SIJEČNJA 2000. VEĆE PLAĆE NIŽE CIJENE \\
\hline & $\begin{array}{l}\text { 3. SIJEČNJA 2000. OTVORIT ĆEMO } 200.000 \\
\text { INOVIH RADNIH MJESTA }\end{array}$ \\
\hline HNS & GRADIMO BUDUĆNOST ZAJEDNO \\
\hline HSLS I DC & 'NOVA SNAGA ZA BOLJU HRVATSKU \\
\hline $\mathrm{HSP}$ & VJERUJ U SEBE \\
\hline HSS & VOLIM SVOJU ZEMLJU \\
\hline \multirow[t]{3}{*}{ LIBRA } & EUROPA 2007. \\
\hline & ODGOVORI NA VAŽNA PITANJA \\
\hline & ZA HRVATSKU ZNANJA \\
\hline LS & $100 \%$ LIBERALNO \\
\hline \multirow[t]{4}{*}{ SDP } & DA ZA SDP - DA ZA HRVATSKU \\
\hline & DA ZA SDP - DA ZA OBITELJ \\
\hline & DA ZA SDP - DA ZA OBRAZOVANJE \\
\hline & DA ZA SDP - DA ZA BUDUĆNOST \\
\hline
\end{tabular}




\begin{tabular}{|l|l|}
\hline DA ZA SDP - DA ZA RAZVOJ \\
\hline DA ZA SDP - DA ZA SIGURNOST \\
\hline DA ZA SDP - DA ZA ZAPOŠLJAVANJE \\
\hline
\end{tabular}

TISAK

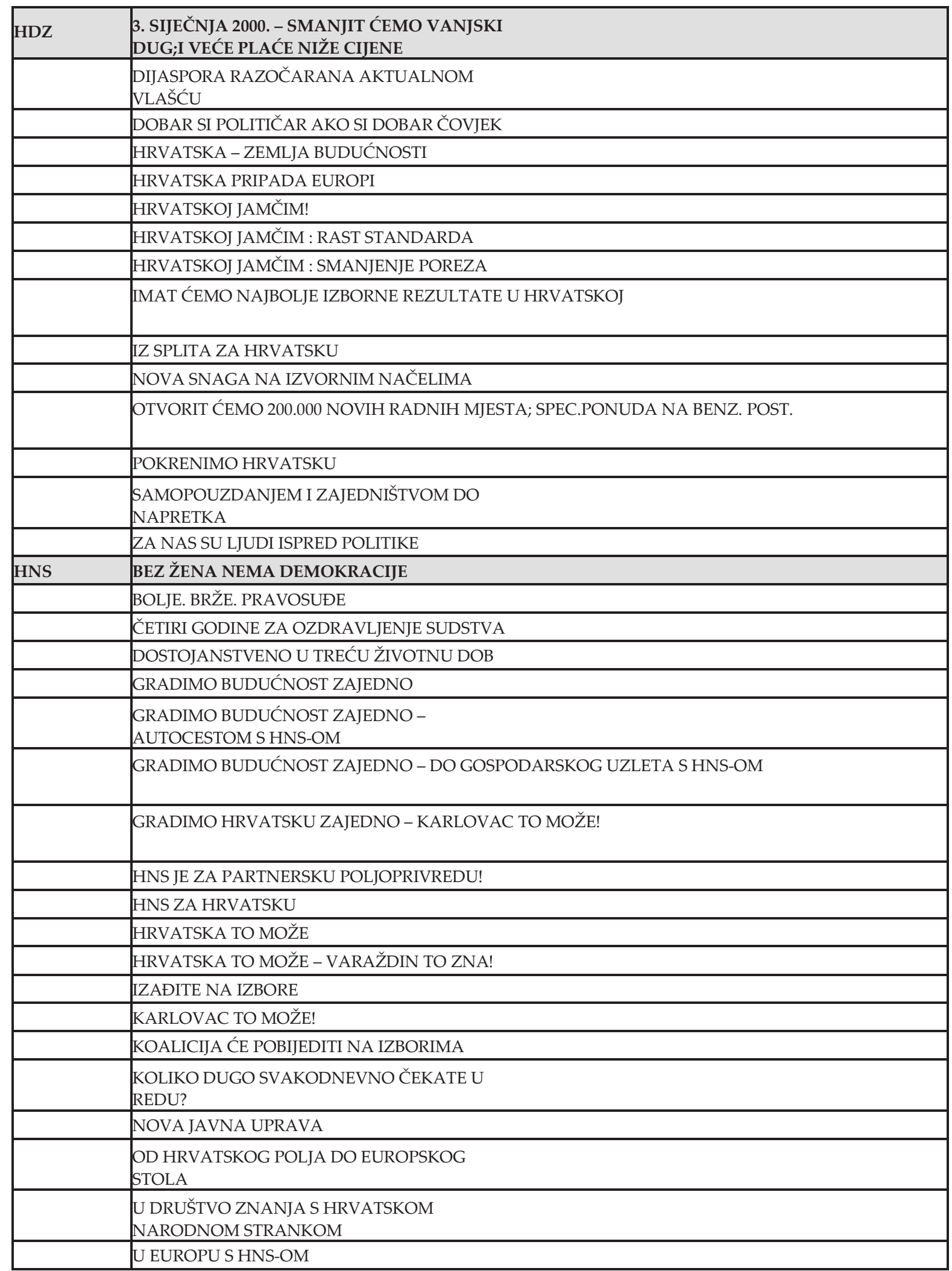




\begin{tabular}{|c|c|}
\hline & U EUROPU S PROJEKTIMA HNS-A \\
\hline & $\begin{array}{l}\text { U SLJEDEĆEM MANDATU OSTVARIT ĆEMO } \\
\text { GOSPODARSKI RAST OD 6,5\% }\end{array}$ \\
\hline \multirow[t]{9}{*}{$\begin{array}{l}\text { HSLS I } \\
\text { DC }\end{array}$} & ČOVIK KOJEM SE VIRUJE! - JOŠKO KONTIĆ \\
\hline & HRVATSKA MOŽE I MORA BIT BOLJA \\
\hline & NAŠ SLOGAN SU LJUDI \\
\hline & $\begin{array}{l}\text { NIJE DOVOLJNO PROMIJENITI VLAST, TREBA } \\
\text { PROMIJENITI GENERACIJU NA VLASTI }\end{array}$ \\
\hline & NOVA SNAGA - TKO ILI ŠTO? \\
\hline & NOVA SNAGA ZA BOLJU HRVATSKU \\
\hline & NOVA SNAGA ZA BOLJU HRVATSKU \\
\hline & PROGRAM ISKRENOSTI \\
\hline & ŽELITE LI I DALJE OVAKVU VLADU? \\
\hline \multirow[t]{3}{*}{ HSP } & HRVATSKA SVJESNA PRAVEDNA \\
\hline & VAŠ GLAS JE DOISTA VAŽAN \\
\hline & VJERUJ U SEBE \\
\hline \multirow[t]{15}{*}{ HSS } & 100 GODINA UZ HRVATSKI NAROD \\
\hline & A ŠTA DRUGO? \\
\hline & ČUVAM MORE ZA SVOJU DICU \\
\hline & $\begin{array}{l}\text { HRVATSKA SELJAČKA STRANKA STRANKA JE } \\
\text { MALOG ČOVJEKA! }\end{array}$ \\
\hline & JA TO MOGU JER VOLIM SVOJU ZEMLJU \\
\hline & $\begin{array}{l}\text { KONCEPT GOSPODARSKOG PROGRAMA } \\
\text { HSS-A }\end{array}$ \\
\hline & KONCEPT KAMPANJE \\
\hline & MEĐIMURKE I MEĐIMURCE! \\
\hline & PRAVE VRIJEDNOSTI TRAJU... \\
\hline & PROJEKT RAZVOJA HRVATSKE \\
\hline & $\begin{array}{l}\text { SVE JE VIŠE ŽENA U HRVATSKOM SRCU I U } \\
\text { HSS-U! }\end{array}$ \\
\hline & VAS GLAS ZA BOLJE SUTRA \\
\hline & VOLI SVOJU ZEMLJU \\
\hline & VOLIM SVOJ GRAD \\
\hline & $\begin{array}{l}\text { ZAŠTO MLADI MEĐIMURJA SVOJU } \\
\text { BUDUĆNOST VIDE U HSS-U! }\end{array}$ \\
\hline \multirow[t]{5}{*}{ SDP } & $1999-2003$ \\
\hline & $\begin{array}{l}\text { 1999: HRVATSKA U KRIZI, } 2003: \text { HRVATSKA U } \\
\text { RAZVOJU! }\end{array}$ \\
\hline & BRŽI RAZVOJ UZ VLASTITA SREDSTVA \\
\hline & DA! - ZA BUDUĆNOST \\
\hline & DA! - ZA HRVATSKU \\
\hline
\end{tabular}




\subsection{Sadržaj negativnih propagandnih poruka po strankama i medijima}

\begin{tabular}{|c|c|c|c|}
\hline STRANKA & $\begin{array}{l}\text { IZBORNA } \\
\text { PORUKA }\end{array}$ & $\begin{array}{l}\text { POZITIVNO/ } \\
\text { NEGATIVNO }\end{array}$ & OPIS SPOTA \\
\hline $\begin{array}{l}\text { HIP I } \\
\text { HRVATSKI } \\
\text { BLOK }\end{array}$ & BUDI SVOJ & NEGATIVNO & 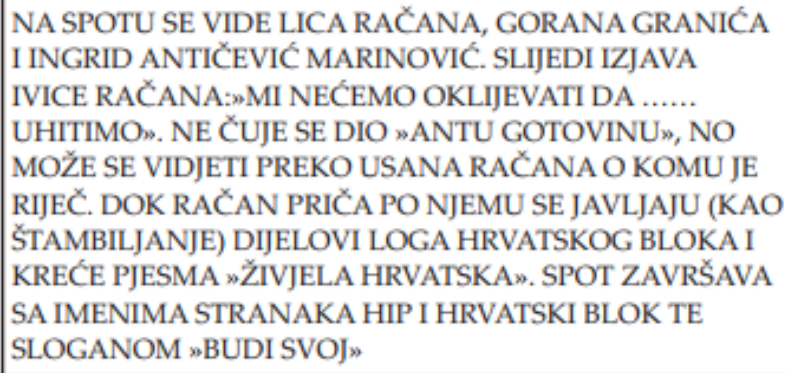 \\
\hline HSLS I DC & $\begin{array}{l}\text { NOVA SNAGA } \\
\text { ZA BOLJU } \\
\text { HRVATSKU }\end{array}$ & NEGATIVNO & $\begin{array}{l}\text { SPOT JE NAPRAVLJEN U OBLIKU DJEČJE SLAGALICE } \\
\text { SA ŽUTO PLAVIM KOCKICAMA. CUJU SE GLASOVI } \\
\text { RAZLIČITIH LJUDI SA PITANJIMA: „ZA KOGA ĆU } \\
\text { GLASATI, KADA ĆU JA DOBITI POSAO, A KADA ĆE SE } \\
\text { POSTTIVATI ZAKONI, RECITE MI TKO ĆE SPRIJECITI } \\
\text { KORUPCIJU, KADA ĆE VLAS POSTATI EFIKASNA, } \\
\text { KAKO POKRENUTI GOSPODARSTVO, POSTOJE LI } \\
\text { RJEŠENJA ZA HRVATSKU, ZA KOGA GLASATI. NAKON } \\
\text { PITANJA SLIJEDI» HSLS I DC - NOVA SNAGA ZA BOLJU } \\
\text { HRVATSKU». CIJELO VRIJEME DOK ČUJEMO GLASOVE } \\
\text { KOJI POSTAVLJAJU PITANJA KOCKICE SE PREMJESTTAJU } \\
\text { I NA KRAJU JE SLOŽENA SLAGALICA NA KOJOJ SE VIDI } \\
\text { TEKST „HSLS I DC, NOVA SNAGA ZA BOLJU HRVATSKU» }\end{array}$ \\
\hline
\end{tabular}

TISAK

\begin{tabular}{|c|c|c|c|}
\hline STRANKA & $\begin{array}{l}\text { IZBORNA } \\
\text { PORUKA }\end{array}$ & $\begin{array}{l}\text { POZITIVNO/ } \\
\text { NEGATIVNO }\end{array}$ & OPIS OGLASA \\
\hline HCXP I HKDU & $\begin{array}{l}\text { DOMOVINSKA } \\
\text { I ISELJENA } \\
\text { HRVATSKA ZA III. } \\
\text { REPUBLIKU }\end{array}$ & NEGATIVNO & $\begin{array}{l}\text { NA OGLASU PIŠE TEKST: »U HRVATSKOJ SU LIJEVI } \\
\text { IZDALI DRŽAVU, A DESNI NACIJU». SLIJEDI POPIS } \\
\text { KANDIDATA HČP-A I HKDU-A }\end{array}$ \\
\hline HČSP I HKDU & $\begin{array}{l}\text { POVUCI PRAVI } \\
\text { POTEZ - PORAZI } \\
\text { CRVENE }\end{array}$ & NEGATIVNO & $\begin{array}{l}\text { NA OGLASU SLIKA ŠAHOVSKOG POLJA - FIGURA SA } \\
\text { PETOKRAKOM JE MATIRNA, TJ. STJERANA U KUT OD } \\
\text { STRANE FIGURE KOJA NA SEBI IMA SIMBOLE HČSP-A I } \\
\text { HKDU-A. }\end{array}$ \\
\hline $\mathrm{HDZ}$ & $\begin{array}{l}\text { 3.SIJECANJ } 2000 \\
\text { - SMANJIT ĆEMO } \\
\text { VANJSKI DUG } \\
\text { I VEĆE PLAĆE } \\
\text { NIŽE CIJENE }\end{array}$ & NEGATIVNO & SLIKA PINOKIJA I SLIKA FIGE \\
\hline $\mathrm{HDZ}$ & $\begin{array}{l}\text { DIJASPORA } \\
\text { RAZOĆARANA } \\
\text { AKTUALNOM } \\
\text { VLAŚĆU }\end{array}$ & NEGATIVNO & $\begin{array}{l}\text { OGLAS SE ODNOSI NA SLAVONSKO - BARANJSKU } \\
\text { VEČERU U STUTTGARTU U ORGANIZACIJI HDZ-A. NA } \\
\text { VEČERI IZJAVU JE DA ZDRAVKO SOČKOVIĆ U IME IVE } \\
\text { SANADERA }\end{array}$ \\
\hline
\end{tabular}




\begin{tabular}{|c|c|c|c|}
\hline $\mathrm{HDZ}$ & $\begin{array}{l}\text { OTVORIT CEMO } \\
200.000 \text { NOVIH } \\
\text { RADNIH MJESTA } \\
\text { I SPECIJALNA } \\
\text { PONUDA NA } \\
\text { BENZINSKIM } \\
\text { POSTAJAMA }\end{array}$ & NEGATIVNO & $\begin{array}{l}\text { SLIKA ČOVJEKA KOJI HODA I KOJEMU SU NOGE SVE } \\
\text { KRAĆE I KRAĆE I SLIKA CESTE NA KOJIMA SE VIDI } \\
\text { AUTOMOBILI I PIŠE EUROSUPER 95 4,23 KN VRIJEDI DO } 3 . \\
\text { SIJEČANJA 2000.G. }\end{array}$ \\
\hline $\mathrm{HDZ}$ & $\begin{array}{l}\text { POKRENIMO } \\
\text { HRVATSKU }\end{array}$ & NEGATIVNO & $\begin{array}{l}\text { SVE CETIRI SLIKE NA JEDNOM OGLASU - SLIKA } \\
\text { PINOKIJA, SLIKA FIGE, SLIKA COVJEKA KOJI HODA I } \\
\text { KOJEMU SU NOGE SVE KRAĆE I KRAĆE I SLIKA CESTE } \\
\text { NA KOJIMA SE VIDI AUTOMOBILI I PIŠE EUROSUPER } 95 \\
\text { 4,23 KN VRIJEDI DO 3. SIJECANJA 2000.G. }\end{array}$ \\
\hline $\begin{array}{l}\text { HIP I } \\
\text { HRVATSKI } \\
\text { BLOK }\end{array}$ & $\begin{array}{l}\text { HRVATSKA } \\
\text { HRVATIMA, A } \\
\text { NE STRATESKIM } \\
\text { INVESTITORIMA }\end{array}$ & NEGATIVNO & $\begin{array}{l}\text { PLAĆENI OGLAS U OBLIKU INTERVJUA SA ŽELJKOM } \\
\text { VRANJEŠEM, PREDSJEDNIKOM OSJEČKO-BARANJSKE } \\
\text { PODRUŽNICE HIP-A. NA OGLASU JE I NJEGOVA SLIKA. U } \\
\text { OGLASU KRITIZIRA AKTUALNU VLAST }\end{array}$ \\
\hline $\begin{array}{l}\text { HIP I } \\
\text { HRVATSKI } \\
\text { BLOK }\end{array}$ & $\begin{array}{l}\text { PAZITE ZA KOGA } \\
\text { ĆETE GLASATI! }\end{array}$ & NEGATIVNO & $\begin{array}{l}\text { IZJAVA VINKA JELIĆA BALTE: } \text { HSS JE IZNEVJERIO } \\
\text { OČEKIVANJA SVOJIH BIRAČA. OSIM ŠTO PRODAJU } \\
\text { DEMAGOGIJU, PRODAJU I ZEMLJU U DRŽAVNOM } \\
\text { VLASNIŠTVU...GLASANJEM ZA HSS ZAPRAVO GLASAJU } \\
\text { ZA KOMUNISTE KOJI ŽELE SRUŠITI VLAST...» }\end{array}$ \\
\hline HNS & $\begin{array}{l}\text { KOLIKO DUGO } \\
\text { SVAKODNEVNO } \\
\text { CEKATE U REDU? }\end{array}$ & NEGATIVNO & $\begin{array}{l}\text { HNS PREDSTAVIO PROGRAM REFORME JAVNE UPRAVE } \\
\text { - DUGI REDOVI SU SVAKODNEVICA ZA HRVATSKE } \\
\text { GRAĐANE }\end{array}$ \\
\hline HNS & $\begin{array}{l}\text { U DRUŠTVO } \\
\text { ZNANJAS } \\
\text { HRVATSKOM } \\
\text { NARODNOM } \\
\text { STRANKOM }\end{array}$ & NEGATIVNO & $\begin{array}{l}\text { HNS PREDSTAVIO PROGRAM REFORME VISOKOG } \\
\text { SKKOLSTVA I ZNANOSTI }\end{array}$ \\
\hline HSLS I DC & $\begin{array}{l}\text { NIJE DOVOLJNO } \\
\text { PROMIJENITI } \\
\text { VLAST, TREBA } \\
\text { PROMIJENITI } \\
\text { GENERACIJU NA } \\
\text { VLASTI } \\
\end{array}$ & NEGATIVNO & $\begin{array}{l}\text { NA OGLASU SAMO PIŠE NAVEDENI TEKST: NIJE } \\
\text { DOVOLJNO PROMIJENITI VLAST, TREBA PROMIJENITI } \\
\text { GENERACIJU NA VLASTI» }\end{array}$ \\
\hline HSLS I DC & $\begin{array}{l}\text { NOVA SNAGA } \\
\text { ZA BOLJU } \\
\text { HRVATSKU }\end{array}$ & NEGATIVNO & $\begin{array}{l}\text { PUNI TEKST OGLASA: GRAĐANI SJEVEROZAPADNE } \\
\text { HRVATSKE! NEZAPOSLENOST JE SMANJENA? } \\
\text { 200.000 RADNIH MJESTA JE OTVORENO? NAŽALOST, } \\
\text { ZAPOSLENOST SE SMANJILA! ZATO NIJE DOVOLJNO } \\
\text { PROMIJENITI VLAST, TREBA PROMIJENITI GENERACIJU } \\
\text { NA VLASTI }\end{array}$ \\
\hline HSLS I DC & $\begin{array}{l}\text { ŽELITE LI I } \\
\text { DALJE OVAKVU } \\
\text { VLADU? }\end{array}$ & NEGATIVNO & $\begin{array}{l}\text { PUNI TEKST OGLASA: GRAĐANI SJEVEROZAPADNE } \\
\text { HRVATSKE! TREBA LI VLADA POMAGATI PRIVATNO } \\
\text { BRODOGRADILIŠTE S MILIJUNIMA DOLARA? A GDJE } \\
\text { SMO MI? ŽELITE LI I DALJE OVAKVU VLADU? VLADA } \\
\text { MORA RAVNOMJERNO POMAGATI HRVATSKOM } \\
\text { GOSPODARSTVU! }\end{array}$ \\
\hline $\begin{array}{l}\text { STRANKA } \\
\text { HRVATSKOG } \\
\text { PREPORODA }\end{array}$ & HRVATI OPREZ! & $\begin{array}{l}\text { IZRAZITO } \\
\text { NEGATIVNO }\end{array}$ & $\begin{array}{l}\text { SLIKA MRTVAČKE GLAVE ISPOD KOJE PIŠE:»PAZITE SE } \\
\text { KOMUNISTA SVAKE VRSTE, PLJAČKAS̆A IZ BILO KOJE } \\
\text { STRANKE, NESPOSOBNIH POLITIĊARA I POLITIČKIH } \\
\text { KRIMINALACA». TAKOĐER I SLIKA BOŽIDARA } \\
\text { MASLOVA, PREDSJEDNIKA SHP I NJEGOVA IZJAVA }\end{array}$ \\
\hline
\end{tabular}




\begin{tabular}{|c|c|c|c|}
\hline $\begin{array}{l}\text { STRANKA } \\
\text { HRVATSKOG } \\
\text { PREPORODA }\end{array}$ & $\begin{array}{l}\text { ZAŠTITIMO } \\
\text { HRVATSKU }\end{array}$ & NEGATIVNO & $\begin{array}{l}\text { ZAŠTITIMO HRVATSKU OD SADAŠNJE VLASTI, } \\
\text { GOSPODARSKOG KRIMINALA, SVAKE VRSTE PLJAČKE, } \\
\text { KORUPCIJE, LUPEŠKE PRETVORBE, BIROKRACIJE, CARLE } \\
\text { DEL PONTE.» }\end{array}$ \\
\hline \multicolumn{4}{|l|}{ OUTDOOR } \\
\hline STRANKA & $\begin{array}{l}\text { IZBORNA } \\
\text { PORUKA }\end{array}$ & $\begin{array}{l}\text { POZITIVNO/ } \\
\text { NEGATIVNO }\end{array}$ & OPIS OGLASA \\
\hline $\mathrm{HDZ}$ & $\begin{array}{l}\text { 3. SIJEĆNJA } 2000 . \\
\text { VEĆE PLAĆE } \\
\text { NIŽE CIJENE }\end{array}$ & NEGATIVNO & SLIKA FIGE \\
\hline $\mathrm{HDZ}$ & $\begin{array}{l}\text { 3. SIJECNJA } 2000 . \\
\text { OTVORIT ĆEMO } \\
\text { 200.000 NOVIH } \\
\text { RADNIH MJESTA }\end{array}$ & NEGATIVNO & $\begin{array}{l}\text { SLIKA CO COVJEKA KOJI HODA I KOJEMU SU NOGE SVE } \\
\text { KRAĆE I KRAĆE }\end{array}$ \\
\hline
\end{tabular}

Broj negativnih poruka po vrstama $i$

strankama

\begin{tabular}{|l|c|c|c|c|}
\hline & Televizija & Tisak & Outdoor & \\
\hline STRANKA & Vrste poruka & $\begin{array}{c}\text { Vrste } \\
\text { poruka }\end{array}$ & $\begin{array}{c}\text { Vrste } \\
\text { poruka }\end{array}$ & Ukupno \\
\hline HIP I HRVATSKI BLOK & 1 & 2 & & 3 \\
\hline HSLS I DC & 1 & 3 & & 4 \\
\hline HDZ & & 4 & 2 & 6 \\
\hline HNS & & 2 & & 2 \\
\hline STRANKA HRVATSKOG PREPORODA & & 2 & & 2 \\
\hline Sveukupno & & & & 17 \\
\hline
\end{tabular}

\section{Investicije u oglašavanje}

Pod investicijama u oglašavanje podrazumijevamo ukupnu vrijednost zauzetog medijskog prostora prema stvarnom cjeniku pojedinog medija za koje se istraživanje radilo. Rabati i ostali mogući dogovori oko visine cijene nisu bili poznati za većinu medija pa je cjenik propagandne poruke $\mathrm{u}$ svim slučajevima izražen prema stvarnom cjeniku..

\subsection{Investicije u oglašavanje po vrsti medija} Iznenađuje visok postotak investicija $u$ vanjsko oglašavanje koje je koncentrirano na urbane sredine jer pod vanjskim oglašavanjem uvrštene su vrijednosti investicija u tzv. outdoor oglase. Ostale vanjske površine, poput tramvaja, autobusa, vlakova i sl., nisu analizirane.
Ukupne investicije $u$ oglašavanje za tri promatrana medija (tisak, TV i vanjsko oglašavanje) od 1.9. do

30.11.03. iznose 829 milijuna kuna (bruto iznos). Od toga iznosa, 526 milijuna kuna je vrijednost TV oglasa (65\%), 213,5 milijuna kuna vrijednost tiskovnih oglasa (27\%) i 67 milijuna kuna je vrijednost vanjskog oglašavanja (8\%). Prikazani podaci ukazuju na snagu industrije oglašavanja koja u BDP-u Hrvatske sudjeluje sa 0,93\% ali i na potencijalnu ovisnost medija o toj industriji. U ovom kontekstu stoji činjenica da mediji prodaju publiku oglašivačima.

Političke stranke su $\mathrm{u}$ istom periodu uložile 37 milijuna kuna (bruto) u reklame na TV, u tisku i outdoor reklame, što čini 4,5\% ukupnih investicija u oglašavanje za isti period.

Najveći dio izdvojen je za vanjsko oglašavanje (14,9 mil. kuna ili 40\%), zatim za tiskovne oglase (11,9 mil. kuna ili 32\%), a najmanje na TV oglašavanje (10,3 mil. kuna ili 28\%). 
Najveće investicije $u$ oglašavanje imali su HDZ i SDP, a slijede HNS i HSLS/DC.

Stranke koje su najviše uložile u marketinšku kampanju ostvarile su najbolje izborne rezultate, ali ako ove podatke dovedemo $\mathrm{u}$ korelaciju $\mathrm{s}$ podacima $\mathrm{o}$ predizbornom raspoloženju birača, medijskoj zastupljenosti i konačnim rezultatima izbornog ponašanja, uočit ćemo da ne postoji bitna razlika, pomak u odnosu na predizborno raspoloženje i izborne rezultate, osim u slučaju HSU.
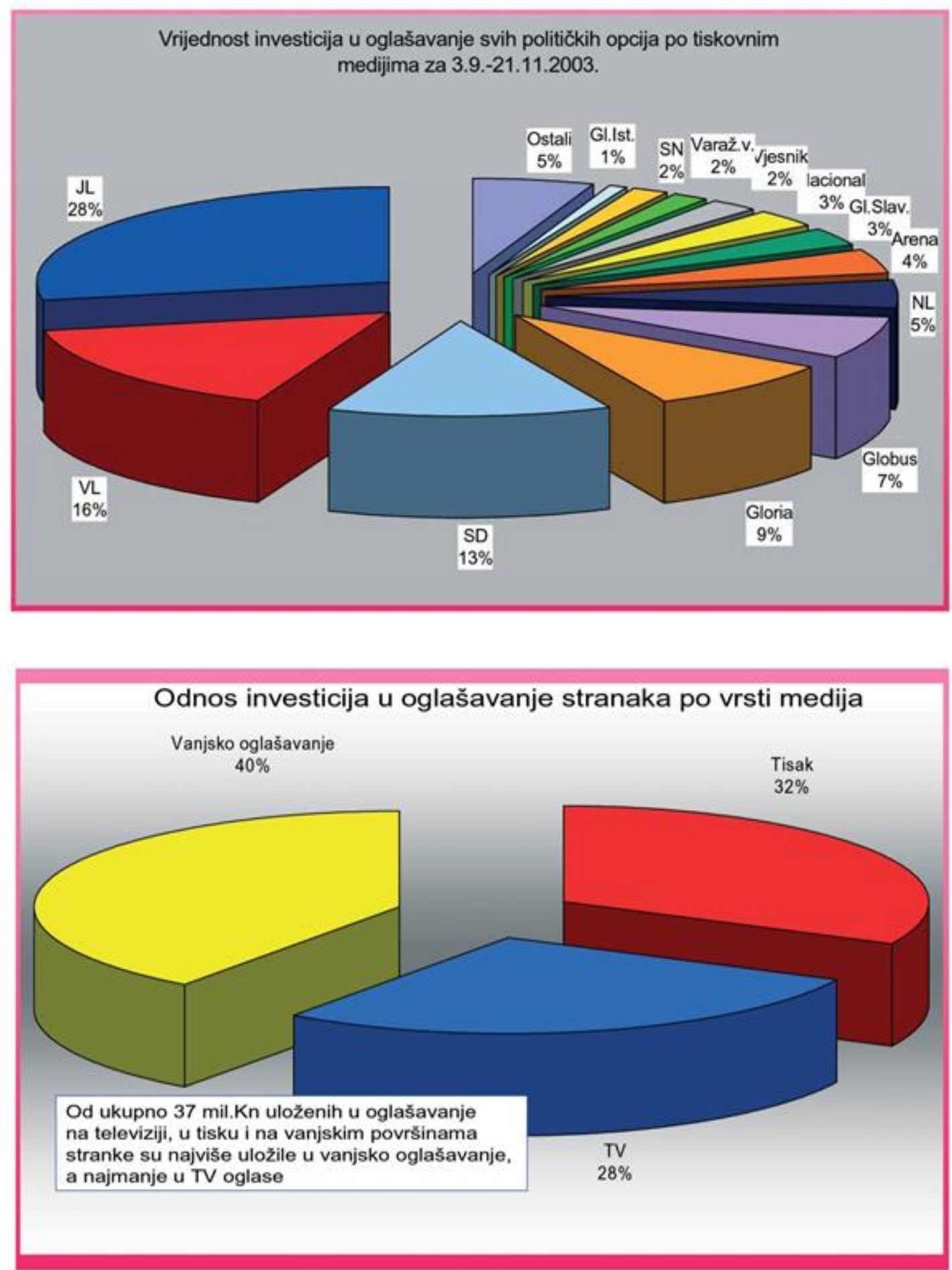

Stranke su najviše novca uložile u reklame na vanjskim površinama, čime nije obuhvaćen stariji, siromašniji i ruralni dio populacije. 
Mario Plenković, Slobodan Hadžić, Mladen Kučiš: MEDIJSKA ZASTUPLJENOST POLITIČKIH OPCIJA I GRAĐANSKO IZBORNO PONAŠANJE

(Case Study: Hrvatski parlamentarni izbori 2003.godine)

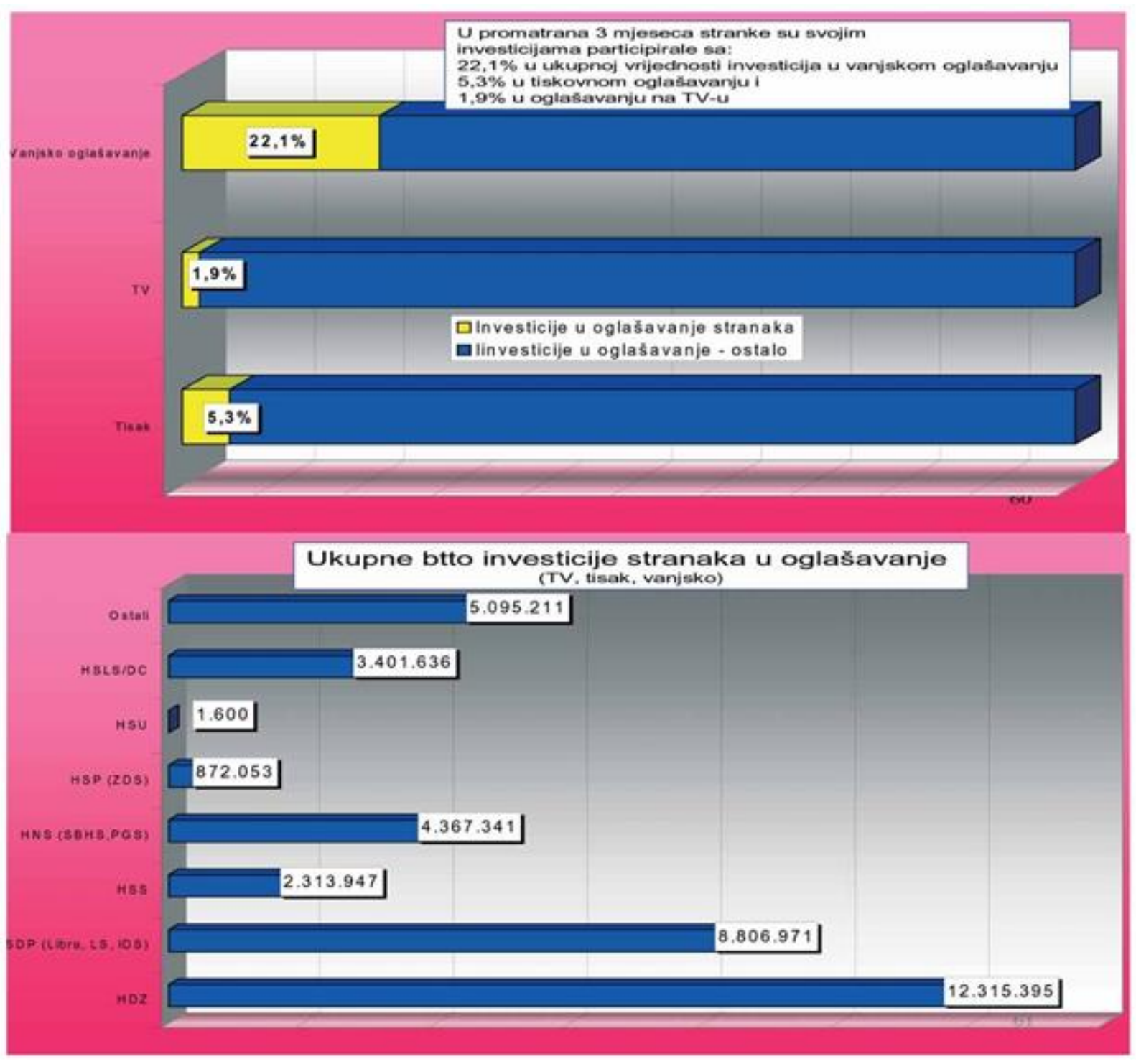




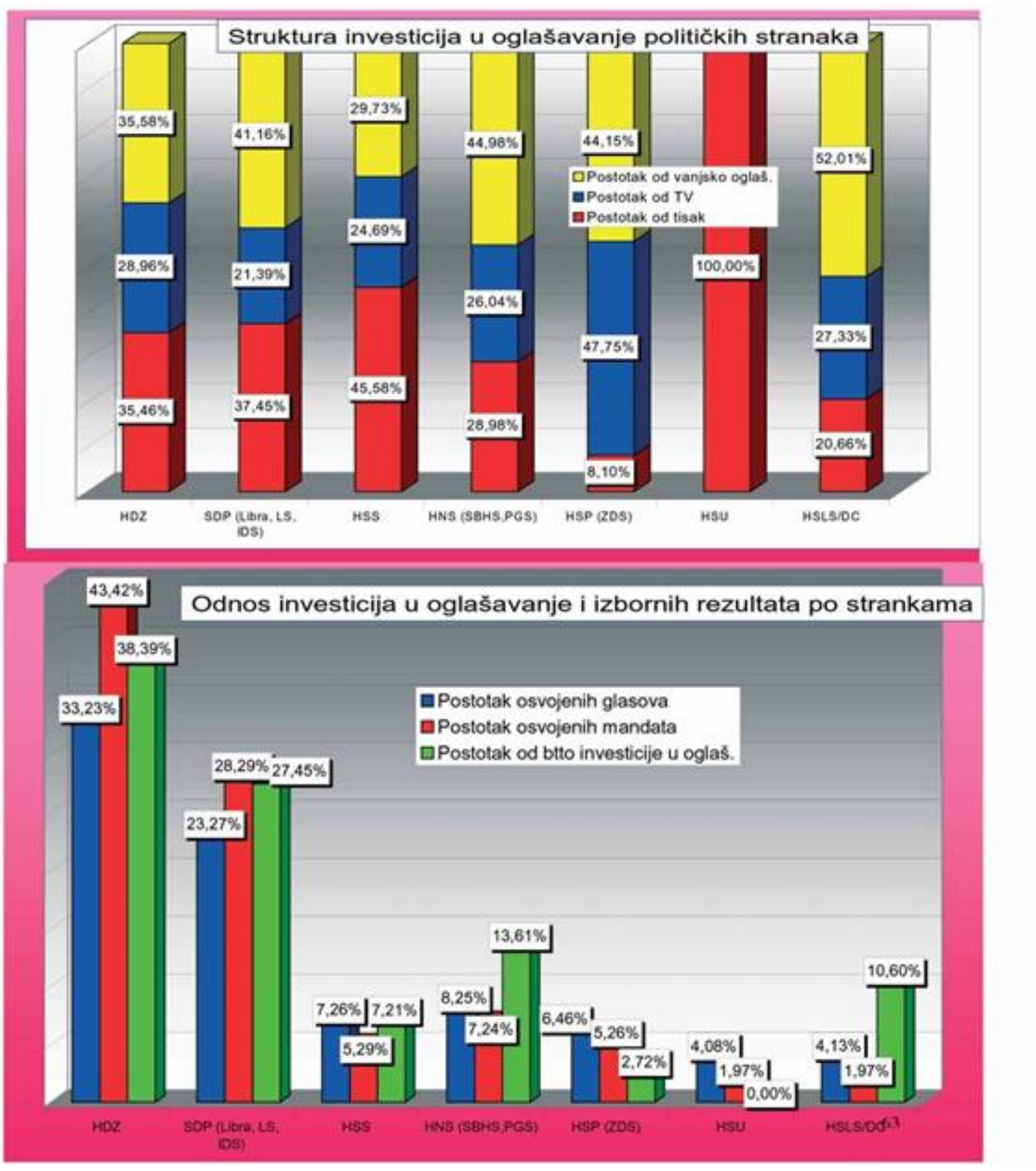

\section{Zaključna razmatranja}

Istraživanjem smo došli do zaključka da ne postoji jednostavan uzročno-posljedičan odnos između medijske zastupljenosti i izbornog ponašanja jer se preferencija birača prije izborne kampanje nakon medijske izloženosti tijekom kampanje nije bitno promijenila $\mathrm{u}$ značajnije promjene izbornog ponašanja.

Nesumnjivo,utjecaj postoji,i to za cjelinu komunikacije političkih stranaka prema publici medija. Kažemo za cjelinu, jer su i medijske objave i propagandni spotovi, bez obzira na različitu uvjerljivost i važnost koja im se pridaje, dio cjelokupne komunikacije stranaka prema potencijalnim biračima. Medijska komunikacija, osim toga, nije jedina komunikacija u predizborno vrijeme. Nismo istraživali druge oblike komunikacije poput stranačkih skupova (internih i javnih), komunikacije stranačkog vodstva sa biračima, sastanaka na lokalnim u drugim razinama, letke i druge oblike propagande i komunikacije. Nastavak istraživanja na prikupljenim podacima je nužan, $i$ to tako da se $u$ istraživački korpus uzme nekoliko stranaka, sadržaj poruka ocjenjuje po njihovoj važnosti i uvjerljivosti (po uzoru na Fanov model), da se 
mogući utjecaj objava vrednuje po sociodemografskim karakteristikama publike svakog pojedinog medija, i to na regionalnoj razini i da se dobiveni pokazatelji usporede sa pokazateljima predizbornog raspoloženja i izbornog ponašanja na istim razinama (regionalnoj ili lokalnoj).

Sljedeći pravac istraživanja usredotočit će se i na sadržaj poruka, glavne teme kampanje, odnos između medijske agende s jedne strane, političke $\mathrm{s}$ druge strane i stvarne $\mathrm{u}$ cilju saznanja kako birači percipiraju medijsku moć u processu izbornog građanskog ponašanja. Dobiveni istraživački rezultati ukazuju da će nastavak ovog sustavnog istraživanja doprinijeti novim istraživačkim, politološkim i komunikološkim spoznajama.

Istraživanje ove problematike predstavljaju novi komunikološki doprinos sustavnom istraživanju dijalektike medijske moći i izbornog građanskog ponašanja $u$ procesu parlamentarnih izbora.

\section{Bilješke}

/1/ F.Vreg: Humana komunikologija, Hrvatsko komunikološko društvo \& Nonacom, Zagreb, 1998. (str.18).

/2/ M.Plenković: Konvergencija hrvatskih medija, Projekt Ministarstva znanosti i tehnologije RH, Studija I, Katedra za komunikoloiju, Grafičlki fakultet Sveučilišta u Zagrebu, Zagreb, 2004. (str. 38).

/3/ Murdochovo uplitanje u u uređivačku koncepciju glasila svakako je napoznatiji primjer

/4/ »Učvršćivanje intencije birača bio je najprimjetniji učinak novina.

Zabilježen je ograničen učinak na promjenu mišljenja i značajan dokaz da su novine stvorile preferencije kod neopredijeljenih. Martin Harrop (1986.) ustanovio je da su novine imale glavni učinak na stavove birača o određenim temama, a manje na ocjenu potencijalnih političkih vođa (za koje je televizija bila glavni izvor).», John Street: Masovni mediji, politika i demokracija, Biblioteka Politička misao, Zagreb, 2003., str. 75

/5/ Isto

/6/ isto, str.76

/7/ Jednostavni modeli medijskih uzroka i posljedica možda više ne vrijede, no to ne znači da trebamo pretpostaviti kako mediji ne utječu na to kako ljudi misle i djeluju. To samo znači da za razumijevanje tog procesa treba uzeti u obzir složenost ljudskog odnosa prema mnogim tekstovima koje primaju, njihovu dvosmislenost $\mathrm{i}$ uvjete $\mathrm{u}$ kojima ih ljudi interpretiraju. Kako piše Garnham (2000., 125): »Medijske poruke utječu na naše shvaćanje svijeta, no kako ćemo mi to shvaćanje interpretirati ili djelovati u skladu s njim, ovisi o društvenom položaju i iskustvu». Trebamo uzeti u obzir načine na koje druge (jednako dvosmislene i kontradiktorne) informacije $\mathrm{i}$ iskustvo oblikuju gle danje ili čitanje. Pišući o vlastitom iskustvu u istraživanju televizijske publike, David Morley (1997., 77) tvrdi: "Medijska komunikacija mora se uklopiti u polja osobne i institucionalne komunikacije na kojima ljudi koji čine publiku postoje i kao birači, kućanice, radnici, trgovci, roditelji, roleri ili vojnici. Sve te institucije, sve te uloge u kojima se ljudi nalaze, proizvode poruke koje se sijeku s medijskim porukama», isto, str. 83

/8/ O vrijednosti ove metode piše i Vesna Lamza Posavec »..analizom sadržaja..neki suvremeni autori pokušavaju predvidjeti rezultate glasovanja na izborima kao njegovu najuočljiviju i najizravnije mjerljivu manifestaciju. Među zapaženijim istraživanjima te vrste je istraživanje Fana i Timsa /1989./ koji su, primjenom »ideodinamičkog» analitičkog modela na sadržaj agencijskih vijesti »Associated Pressa», vrlo precizno predvidjeli rezultate američkih predsjedničkih izbora /Bush- Dukasis/ 1988. godine. U tijeku osamdesetih godina u slične su svrhe analizu sadržaja koristili i neki drugi autori /npr. Page, Shapiro\&Dempsey, 1989., Allen, 1982. i MacKuen, 1983, prema Fan\&Tims, 1989./ zainteresirani za povezanost trendova medijskog sadržaja $\mathrm{s}$ trendovima javnog mnijenja.» Vesna Lamza Posavec, "Javno mnijenje», Alinea, Zagreb, 1995. godine, str. 49-50.

19/ Količinu, vrijednost i vrstu propagandnih spotova na vanjskim površinama dobili smo susretljivošću agencija

/10/ U prikupljanju, selekciji, obradi i provjeri tijekom tri mjeseca istraživanja sudjelovale su 22 osobe iz tvrtke Medianet i 6 osoba iz tvrtke Presscut pa im se ovim putem zahvaljujemo na prikupljenim i obrađenim podacima.

/11/ Svi žanrovi prema poznatoj i prihvaćenoj kategorizaciji M. Plenkovića.

/12/ Svjesni činjenice da način interpretacije vijesti,uz dužno poštivanje zanatskih pravila $5 \mathrm{~W}$, može kod primatelja izazvati različita značenja uvjetovana dobrim dijelom i načinom 
prezentacije, opredijelili smo se za tretiranje vijesti i izvještaja kao neutralne kategorije.

/13/ McCOMBS I SHAW (1972.)

- proučavali učinke medija na ishod predsjedničkih izbora 1968.

- dotadašnje uvjerenje da informacije i način na koji ih se iznosi utječu na promjene u ponašanju pokazali netočnim

- istraživanja s ponašanja i stavova preusmjerili na svijest o temama i njihovu važnost

FUNKHOUSER (1973.)

- zaključio da medijska tematika utječe na javnu tematiku

\section{COBB I ELDER (1972.)}

- ponekad pojave (eng. triggering devices) aktiviraju određenu temu i učine je bitnom

- primjer: nakon što su 1984. emitirane prve snimke izgladnjele etiopske djece $u$ večernjim vijestima na NBC-ju, uslijedilo je 10-mjesečno razdoblje intenzivne medijske pozornosti i humanitarne aktivnosti; u Brazilu je istovremeno trajala najduža suša u njegovoj povijesti, ali logistika je zakazala: umjesto da su, kao u Etiopiji, lokacije za hranjenje prostorno približili radi efekta masovnosti, one su bile razbacane po zemlji; dojam je bio slabiji, "nije bilo materijala za kamere"

WINTER I EYAL (1981.)

- analiza sadržaja New York Timesa u usporedbi s rezultatima ispitivanja mišljenja agencije Gallup Poll - željeli ustanoviti »optimalno razdoblje za učinak» ili korelacijski vrhunac između sadržaja u medijima i pozornosti javnosti

- zaključak: optimalno korelacijsko razdoblje je od 4 do 6 tjedana

BROSIUS I KEPPLINGER (1990.)

- uspoređivali analizu sadržaja njemačkih tiskovina s 53 ispitivanja javnog mnijenja ( $\mathrm{kroz}$ 53 tjedna 1000 ljudi tjedno odgovaralo je na jedno pitanje)

- također smatraju da je vremenski interval presudan, ali uvode razliku između statičkog i dinamičkog učinka

- dinamički učinak: objave mogu aktualizirati neku temu, ali i tema može potaknuti neku objava

FAN (1988.)

- primjenom matematičkog modela kojeg je nazvao ideodinamičkim predviđao je trendove $u$ ispitivanjima javnog mnijenja iz računalne analize medijskog sadržaja šest izdanja

- zaključio da utjecaj na mišljenje počinje odmah i da se utjecaj poruka masovnih medija eksponencijalno smanjuje nakon samo jednog dana -24 sata.

- njegova metoda je statistički valjana i uspio je predvidjeti izborno ponašanje, dakle javno mnijenje.
/14/ Prema rezultatima IRI-jevog javnomnijenjskog istraživanja stavova $\mathrm{O}$ temeljnim problemima društva

/15/ Korišteni su rezultati iz javnih izvora

/16/ Vjerojatnost rizika, odnosno pogreške pri procjeni

/17/ Iz javno dostupnih podataka IRI-jevog istraživanja

/18/ France Vreg, Humana komunikologija, Biblioteka komunikologijske znanosti, Zagreb, 1998., str. 18

/19/ Isto, str. 19

/20/ „Kad je protivnik neprijatelj, a ne suparnik, pažnja se ne usmjerava na proces nego na karakter protivnika....Kad je definiran kao subverzivan, liberal ne neprijatelj. To je i strana zemlja koja se opaža kao ona koja namjerava potkopati »slobodni svijet»/ili »narodnu demokraciju»/. Ako neprijatelj ne čini ništa vidljivo, to je već po sebi dokaz za njihove podzemne aktivnosti na rušenju društva. U tom obliku konstrukcije motiv nije pobijediti $u$ okršaju nego uništiti protivnika», Murray Edelman, Konstrukcija političkog spektakla, Politička kultura, Zagreb, 2003., str. 81

/21/ Ivan Šiber, Politički marketing, izdanje Politička kultura, Zagreb, 2003. godine, str. 210 do 216, daje razradu vrsta spotova prema F. Luntz, /Candidates, Consultants and Campaigns, Bsil Blackwell, USA, 1988. godine.

/22/ Isto, str.213

/23/ Isto, str.214

\section{Literatura}

1. Street J. Masovni mediji, politika i demokracija, Biblioteka Politička misao, Zagreb, 2003.

2. Noris P, Curtice J, Sanders D, Scammell M, Semetko H. On Message: Communicating the Campaign, London, Sage, 1999.

3. Edelman M. Konstrukcija političkog spektakla, Politička kultura, Zagreb, 2003.

4. Keane J. The media and democracy, Polity Press, Cambridge, 1991.

5. Lamza Posavec V. Javno mnijenje, Alinea, Zagreb, 1995.

6. Plenković M. Teorija i praksa suvremenog novinstva, Grafoimpeks, Zagreb, 1987.

7. Plenković M. Demokratizacija masmedija, CIP, Zagreb, 1980.

8. Plenković M. Poslovna komunikologija, Alinea, Zagreb, 1991.

9. Plenković M. Komunikologija masovnih medija, Barbat, Zagreb, 1993. 
10. Plenković M. Novi sustav javnog komuniciranja, Novosti, Vinkovci, 1990.

11. Plenković M. Krizno komuniciranje i teorije odnosa s javnostima, $\mathrm{u}$ »Mediji, kultura i odnosi s javnostima, br. 1., 2002., Hrvatsko komunikološko društvo, Zagreb, 2002.

12. Plenković, M., Hadžić,S., Kučiš, M., (2006), The dialectic of media power and the electoral behaviour of citizens ( The 2003 general elections in Croatia), Informatol, Vol.39,No. 1,2006., p. 121.

13. Ivoš E. Izazovi modernoj državi, Sveučilište u Splitu, Zadar, 1998.

14. Šiber I. Politički marketing, Politička kultura, Zagreb, 2003.

15. Kesić T. Ponašanje potrošača, Adeco, Zagreb, 1999.

16. Klein N. No logo, Biblioteka Tridvajedan, Zagreb, 2000.

17. Medijsko zakonodavstvo Republike Hrvatske, Biblioteka Kulturni razvitak, Zagreb, 2003.

18. Kasapović M, Šiber I, Zakošek N. Birači i demokracija, Alinea, Zagreb, 1998.

19. Kasapović M. Izborni i stranački sustav Republike Hrvatske, Alinea, Zagreb, 1993.
20. Edelman M. Konstrukcija političkog spektakla, Politička kultura, Zagreb, 2003.

21. Keane J. The media and democracy, Polity Press, Cambridge, 1991.

22. Lamza Posavec V. Javno mnijenje, Alinea, Zagreb, 1995.

23. Zbornik radova, Trenutak hrvatske komunikacije, Zagreb, 1995.

24. Informatologija, Novinarstvo i demokracija / Journalism and Democracy, 29/30. 1996., 3-4. 1997., Hrvatsko komunikološko društvo, Zagreb, 1998.

25. Grbavac V., Kučiš V., Popović G., Hrvatski mediji na prijelazu u 21. stoljeće : Koncepcijski i strateški pristup, Informatologija br. 28, 12/1996., Hrvatsko komunikološko društvo, Zagreb, 1997., str. 33-46.

26. Plenković J., Virtualno društvo, Sveučilište u Rijeci, 1999.

27. Istraživačko novinarstvo, Hrvatsko komunikološko društvo \& Nonacom, OsijekZagreb, 1993.

28. David P.Fan, Predictions of Public Opinion from the Mass Media, Green

\title{
MEDIA PRESENCE OF POLITICAL OPTIONS AND CIVIL ELECTION BEHAVIOR
}

\section{(Case Study: Croatian Parliamentary Elections 2003)}

\author{
Mario Plenković1, Slobodan Hadžić , Mladen Kučiš ${ }^{2}$ \\ University of Zagreb, Faculty of Graphic Arts, Zagreb, Croatia \& Alma Mater Europaea - ECM \& University of Maribor, \\ Faculty of Electrical Engineering, Computing and Informatics, Institute of Media Communications, Maribor, Slovenia ${ }^{\text {, }}$ \\ Croatian Communication Society, Zagreb, Croatia ${ }^{2}$
}

\begin{abstract}
The paper deals with exploratory, political and communication studies of the dialectics of media power or powerlessness in the process of electoral civic behavior on the example of the Croatian parliamentary elections in 2003. The survey covers time limits from September 1 to November 30, 2003. The chosen methodology and the applied research methods are in line with contemporary research trends applied in similar media and electoral and political campaign studies. The authors point to all the complexity of studying this issue, which is catching the attention of recent communication and political science publics. The initial research hypothesis fully confirmed the predicted research results. The author's research focuses on examining the interrelationships between the media representation of political
\end{abstract}


options, persons and electoral civic behavior. An inductive-deductive analysis of media representation was also carried out in correlation with the financial resources spent on publicity and publicity campaigns. The results obtained show that there is no significant causal relationship between media representation and electoral civic behavior. In the final interpretation of the results obtained, it is evident that, prior to the election campaign, attitudes towards electoral preference of voters did not change significantly during the media's publicity and propaganda election civic exposure. Based on the published article "Media Power Dialectics and Electoral Civic Behavior (Croatian Parliamentary Elections 2003), Informatol, Vol.39, No. 1,2006, a political and communicative retrospective discussion was held on the subject of Case Study analysis "Croatian Parliamentary Elections 2003". The research was presented on the occasion of the 50th anniversary of INFORMATOLOGIA (1969 - 2019), at the 25th International Scientific Conference "SOCIETY AND TECHNOLOGY 2019" ("DIT - 2019" - Dr. Juraj Plenković), Opatija, 28. - 30.06. 2019.

Keywords

Parliamentary elections, media, advertising 